\title{
ДЕМОГРАФИЧЕСКИЕ ПОСЛЕДСТВИЯ ВЕЛИКОЙ ОТЕЧЕСТВЕННОЙ ВОЙНЫ *
}

\author{
АНАТОЛИЙ ВИШНЕВСКИЙ ${ }^{1, * *}$
}

\begin{abstract}
С начала Великой Отечественной войны прошло 75 лет. На протяжении всего этого времени Россия ощущала демографические последствия войны, они не полностью изжиты и сейчас. На основе данных всеобщих переписей населения, начиная с переписи 1939 г., в статье прослеживается судьба воевавших поколений (1890-1926 годов рождения), показано, что до 1959 г. дожило $82 \%$ зарегистрированных переписью 1939 г. женщин из этих поколений и всего 53\% мужчин. Образовавшийся гендерный дисбаланс стал причиной резкого увеличения доли одиноких женщин как вследствие овдовения, так и вследствие дефицита женихов на брачном рынке; значительно увеличилась доля внебрачных рождений. Война запустила цикл колебаний годовых чисел рождений, которые продолжаются до сих пор. Относительно небольшое число смертей в послевоенные десятилетия, обусловленное тем, что огромное число погибших во время войны не дожили до нормального срока своей смерти, создавало иллюзию благополучного баланса рождений и смертей в 1970-е-1980-е годы. Порожденные войной циклические колебания численности поколений обусловили волнообразную динамику трудоспособного населения и демографической нагрузки, усложнив функционирование рынка труда и реализацию экономических и сочиальных программ, что также ощущается и в наши дни, например в динамике пенсионных контингентов.
\end{abstract} \begin{abstract}
Автор обсуждает причины огромных военных потерь и высказывает мнение, что если бы войне не предшествовали ошибочные решения политического руководства страны, эти потери могли быть намного меньшими.
\end{abstract}

Ключевые слова: воевавшие поколения, военные потери, последствия войны, цена победы, гендерный дисбаланс.

\section{ЭКСПОЗИЦИЯ: ПЕРЕПИСЬ НАСЕЛЕНИЯ 1939 ГОДА}

22 июня 2016 г. исполнилось 75 лет со дня начала самой страшной за всю историю России войны. Как и другие республики бывшего СССР, Российская Федерация понесла в этой войне огромные, небывалые демографические потери. Оценить прямые людские потери военного времени непросто. Пока шла война, было не до скрупулезного учета потерь (хотя какой-то учет, конечно, велся). Он не слишком интересовал советское руководство и сразу после войны - скорее, напротив, тогда оно стремилось избежать достоверной оценки потерь. Тема эта волновала многих, породила огромную литературу, споры вокруг оценок не утихают до сих пор, и окончательная точка в этих спорах едва ли когда-нибудь будет поставлена.

\footnotetext{
${ }^{1}$ НАЦИОНАЛЬНЫЙ ИССЛЕДОВАТЕЛЬСКИЙ УНИВЕРСИТЕТ «ВЫСШАЯ ШКОЛА ЭКОНОМИКИ» (РОССИЯ).

* В СТАТЬЕ ИСПОЛЬЗОВАНЫ РЕЗУЛЬТАТЫ ИССЛЕДОВАНИЙ, ВЫПОЛНЯВШИХСЯ В РАМКАХ ПРОГРАММЫ ФУНДАМЕНТАЛЬНЫХ ИССЛЕДОВАНИЙ НИУ ВШЭ В 2013-2015 ГГ.

**E-mail: avishnevsky@hse.ru

СТАТЬЯ ПОСТУПИЛА В РЕДАКЦИЮ В ЯНВАРЕ 2016 Г.
} 
Эта статья посвящена не прямой оценке демографических потерь, a демографическим последствиям войны, которые ощущаются и до сих пор. В отличие от обширной литературы о военных потерях, всегда опирающейся на анализ по неизбежности неполных данных, полученных из самых разных, часто противоречащих друг другу источников, наша статья использует только официальные данные государственной статистики, прежде всего результаты всеобщих переписей населения ${ }^{1}$, начиная с переписи 1939 г., зафиксировавшей все мобилизационные контингенты будущего «бессмертного полка», и кончая переписью 2010 г., до которой дожили немногие ветераны.

Перепись населения СССР 1939 г. имеет не самую лучшую репутацию. Она была проведена в январе 1939 г. взамен предыдущей переписи 1937 г., объявленной «дефектной», как считают многие исследователи, потому что она не показала ту численность населения, которую хотело видеть тогдашнее руководство страны, и новая перепись любой ценой должна была устранить этот недостаток. Через три месяца после переписи, в марте 1939 г., в Москве проходил XVIII съезд ВКП(б). В отчетном докладе ЦК ВКП(б), сделанном Сталиным на этом съезде, без упоминания о переписи и как бы невзначай была названа численность населения СССР. Сравнивая Россию с Англией, докладчик заметил, что «населения у нас в несколько раз больше, чем в Англии, стало быть, и потребностей больше, чем в Англии: в Советском Союзе 170 миллионов населения, а в Англии не более 46 миллионов» [Сталин 1997: 305]. Часто полагают, что эта, данная как бы вскользь оценка, прозвучала в докладе Сталина все же не случайно, а для того, чтобы указать статистикам, какого результата ожидало от них руководство страны, и именно о таком результате (170126 тыс. человек) через 10 дней, 21 марта, доложили ему и Молотову председатель Госплана СССР Н.А. Вознесенский и начальник ЦУНХУ И.В. Саутин [Волков 2014: 146147; Андреев, Дарский, Харькова 1993: 31; Тольц 2004]. Существует и другая точка зрения, согласно которой председатель Госплана и начальник ЦУНХУ до съезда не могли знать, какой численности населения ожидал от них Сталин, и у него не было возможности сообщить им об этом иначе, как с трибуны съезда партии, тем не менее уже 5 марта Саутин в докладной записке проинформировал руководство страны о том, что численность населения СССР составляет около 170 млн человек, так что «Сталин огласил цифру, которую ему сообщили статистические органы, а не наоборот» [Башкин, Назаров 2014]2.

В любом случае перепись населения 1939 г. дает последнее более или менее точное представление о предвоенном населении СССР, в том числе и о населении России, которое в то время составляло около 65\% населения СССР. Нам представляется, что даже если использование результатов этой переписи с учетом их вполне вероятной фальсификации и

1 Данные всех переписей населения можно найти на сайте Демоскопа Weekly по адресу http://demoscope.ru/weekly/pril.php.

${ }^{2}$ К этому можно только добавить, чтобы картина стала более объемной, что три предшественника И. Саутина на посту руководителя статистических органов СССР - Валериан Оболенский (Осинский), Иван Краваль и Иван Верменичев - к моменту прихода Саутина на этот пост были один за другим расстреляны, а всего из восьми довоенных руководителей главного статистического ведомства страны было расстреляно пять. Саутин уцелел, но Вознесенский, подписавший вместе с ним докладную записку 21 марта 1939 г., также был казнен, правда, уже позднее, после войны, на протяжении которой он в качестве председателя Госплана СССР руководил всей советской экономикой, совершившей невозможное и обеспечившей к концу войны огромное превосходство над противником в производстве вооружений. 
требует определенных оговорок, влияние такой фальсификации на наши последующие расчеты все же не может быть большим. Если население СССР и было искусственно завышено путем приписки нескольких миллионов «мертвых душ» (по разным оценкам, 1-2 млн человек для всего СССР [Цаплин 1989: 180], порядка 3 млн [Волков 2014: 175], 1,7 млн [Андреев, Дарский, Харькова 1993: 33]), то эти приписки были распределены между разными республиками, население России, по оценкам, было завышено менее, чем на полмиллиона человек [Андреев, Дарский, Харькова 1998: 41]. Такое завышение не может существенно повлиять на структурные соотношения и значительно изменить численность отдельных половозрастных групп населения России общей численностью около 110 млн человек.

С точки зрения демографии, 75 лет - небольшой срок. Если мерить его длиной поколения - в демографическом смысле это среднее время, которое проходит между рождением ребенка и моментом, когда он сам становится родителем, - то 75 лет - это примерно всего три цикла таких превращений. И все эти 75 лет мы ощущали, может быть, даже и не отдавая себе в этом отчета, незаживающие раны войны.



\section{Рисунок 1. Возрастная пирамида населения России по переписи населения 17 января 1939 г., человек}

Перепись населения 1939 г. дает последнее более или менее точное представление о предвоенном населении России (как и всего СССР, но в этой статье речь идет только о России). Основной, непосредственно воевавшей в 1941-1945 гг. частью населения были мужские поколения 1890-1926 гг. рождения. Они и понесли наибольшие потери. Конечно, возрастные границы между участвовавшими и не участвовавшими в боевых действиях поколениями несколько размыты, в них принимали участие и женщины, потери несло и 
мирное население, так что сводить все только к потерям указанных мужских когорт нельзя. Но все же главный удар приняли на себя они.

На рисунке 1 представлена возрастная пирамида населения России по переписи 1939 г. В нижней ее части мы видим глубокую впадину - страшный след голода 1932-1933 гг., но это не относится к теме нашей статьи. Нас интересует та часть пирамиды, которая охватывает поколения россиян, родившихся в период с 1890 по 1926 г.

Для простоты будем далее называть эти поколения «воевавшими поколениями». В 1939 г. они составляли большинство населения России - 58\% всех мужчин и почти 57\% всех женщин (таблица 1).

Таблица 1. Численность населения России по переписи 1939 г.

\begin{tabular}{|c|c|c|c|}
\hline & Мужчины & Женщины & Оба пола \\
\hline $\begin{array}{l}\text { Все поколения, млн человек } \\
\text { в том числе поколения 1890-1926 гг. }\end{array}$ & 51,1 & 57,3 & 108,4 \\
\hline млн человек & 29,6 & 32,6 & 62,2 \\
\hline в \% ко всему населению & 58,0 & 56,9 & 57,4 \\
\hline
\end{tabular}

В свою очередь, воевавшие поколения были неоднородными с точки зрения их предшествовавшей истории, которая наложила свою печать на численность и структуру населения. В январе 1939 г., когда проходила последняя предвоенная перепись населения, представителям этих поколений было от 12 до 48 лет. Часть из них появились на свет в лихолетье Первой мировой и Гражданской войн (1915-1921 гг.), низкая рождаемость этих лет оставила глубокую выбоину на возрастной пирамиде. За 6 лет перед Первой мировой войной (с 1909 по 1914 г.) в России родилось 27,9 млн детей, за 6 лет послевоенных, когда улеглись уже и бури Гражданской войны (с 1923 по 1928 г.) - 27,4млн. А за такой же срок в 1916-1921 гг. - всего 20 млн (1915 и 1922 г. были переходными от мира к войне и от войны к миру).

Для значительной части воевавших поколений это была уже не первая война. Если принять, разумеется, с определенной долей условности, что в Гражданской войне могли участвовать мужчины в возрасте 17 лет и старше и что эта война закончилась в 1921 г., то в ней в той или иной степени участвовали поколения, родившиеся до 1905 г. Эти поколения в 1939 г. составляли свыше 27\% мужчин и почти 30\% женщин воевавших поколений, у них к этому времени уже была существенно нарушена половая пропорция: на 100 женщин приходилось всего 83 мужчины (таблица 2).

Таблица 2. Воевавшие поколения по данным переписи населения 1939 г.

\begin{tabular}{|c|c|c|c|c|c|c|c|c|}
\hline \multirow[b]{3}{*}{ Годы рождения поколений } & \multicolumn{6}{|c|}{ Численность поколений } & \multirow[b]{3}{*}{$\begin{array}{c}\text { Женский } \\
\text { перевес, } \\
\text { млн }\end{array}$} & \multirow[b]{3}{*}{$\begin{array}{c}\text { Мужчин } \\
\text { на } 100 \\
\text { женщин }\end{array}$} \\
\hline & \multicolumn{3}{|c|}{ млн человек } & \multicolumn{3}{|c|}{$\%$} & & \\
\hline & 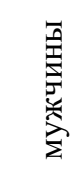 & $\begin{array}{l}\text { 惫 } \\
\text { 罯 } \\
\text { 参 }\end{array}$ & 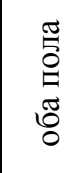 & 恶 & $\begin{array}{l}\text { 量 } \\
\text { 慁 } \\
\text { 冚 }\end{array}$ & 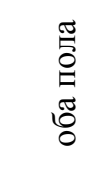 & & \\
\hline $1890-1926$ & 29,6 & 32,6 & 62,2 & 100,0 & 100,0 & 100,0 & 2,9 & 91 \\
\hline \multicolumn{9}{|l|}{ в том числе: } \\
\hline $1890-1904$ & 8,1 & 9,7 & 17,7 & 27,2 & 29,7 & 28,5 & 1,6 & 83 \\
\hline $1905-1922$ & 16,3 & 17,6 & 33,9 & 55,1 & 54,1 & 54,5 & 1,3 & 93 \\
\hline $1923-1926$ & 5,3 & 5,3 & 10,6 & 17,8 & 16,3 & 17,0 & 0,0 & 99 \\
\hline
\end{tabular}


Самая многочисленная составляющая воевавших поколений - родившиеся в 19051922 гг. и еще не участвовавшие в войне. Им в начале 1939 г. было от 16 до 33 лет (значит, в 1941 г. - от 18 до 35 лет), они составляют примерно 55\% воевавших поколений. В них входят и малочисленные поколения 1916-1921 гг. рождения, им в момент переписи было от 17 до 22 лет, мужчин - всего 4,8 млн (на 1,3 млн меньше, чем мужчин в возрасте 24-29 лет). Через два года, когда начнется война, эти малочисленные поколения достигнут возраста от 19 до 24 лет. У всей группы поколений 1905-1922 гг. рождения в целом на 100 женщин приходится не 83 мужчины, как в предыдущей группе, а 93, половая пропорция намного лучше, но все же и она нарушена, прежде всего за счет поколений, родившихся в 1915-1917 гг. Возможно, это связано с более высокой смертностью новорожденных мальчиков в эти годы.

Наконец, еще одна группа - подростки 12-15 лет, родившиеся в 1923-1926 гг. У них половая пропорция не нарушена, но в 1941 г. им будет уже 14-17 лет, а в 1944 г. - 17-20 лет. Им еще предстоит повоевать, хотя и не в самый тяжелый период войны.

\section{СМЕРТНЫЙ ПУТЬ БЕССМЕРТНОГО ПОЛКА}

Как известно, Сталин не разрешил провести после войны перепись или хотя бы упрощенный учет населения СССР, из-за этого очень важная информация о демографических итогах войны была безвозвратно утрачена. Однако последствия демографических потрясений не затухают очень долго, возрастная пирамида хранит память о них многие десятилетия. Первая послевоенная перепись, хотя и прошедшая лишь в 1959 г., через 20 лет после предыдущей переписи 1939 г. и почти через 15 лет после окончания войны, показала очень многое из того, что хотел скрыть Сталин, а все последующие переписи, вплоть до переписи 2010 г., позволяют увидеть, как уходили от нас воевавшие поколения.

На рисунке 2 и в таблице 3 мы видим, как складывалась их демографическая судьба до 1979 г. В 1939 г. (рисунок 1) правая и левая части возрастной пирамиды тоже были не вполне симметричны, но их асимметрия все же не бросалась в глаза при первом взгляде на пирамиду. Прошло 20 лет, контур пирамиды сжался с обеих сторон, но асимметрия стала просто кричащей. И она продолжала нарастать, 20 лет спустя, к 1979 г., она сделалась еще более выраженной: мужская часть воевавших поколений уходила из жизни быстрее, чем женская.

Между переписями 1939 и 1959 гг. численность воевавших поколений сократилась на 19,7 млн человек, при этом потери мужских поколений превышают потери женских на 8,2 млн (таблица 3). Хотя эту разницу нельзя, конечно, автоматически отождествлять с фронтовыми потерями, затронувшими в основном мужчин, она, видимо, достаточно близка к ним, потому что не связанные с боевыми действиями трудности военного времени, а затем и нелегкой послевоенной жизни испытывались в равной степени и мужчинами, и женщинами. 

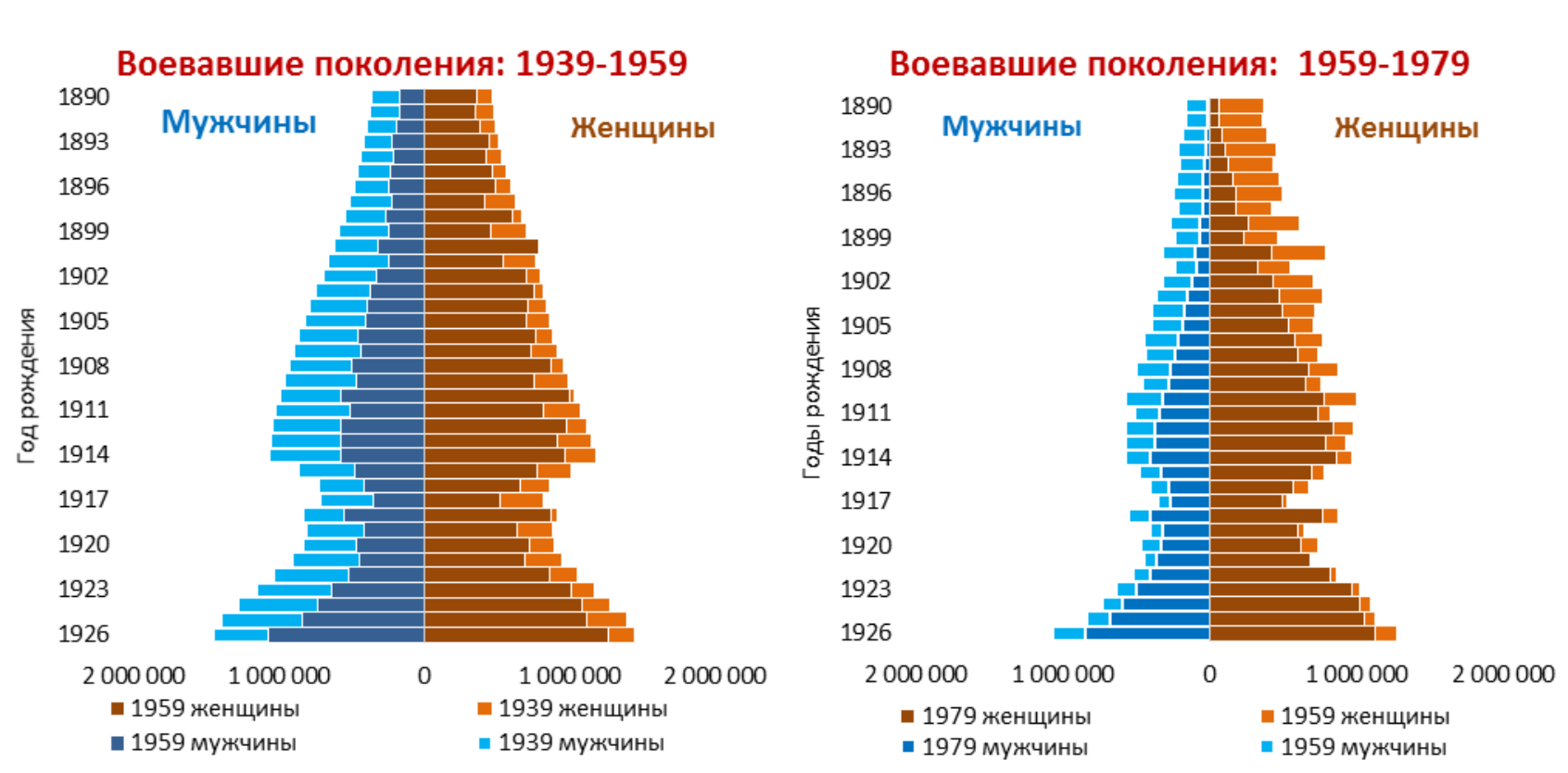

Рисунок 2. Возрастные пирамиды воевавших поколений в 1939-1959 и в 1959-1979 гг. по данным Всесоюзных переписей населения, человек

Таблица 3. Воевавшие поколения в 1939, 1959 и 1979 г.

\begin{tabular}{l|c|c|c}
\hline & Мужчины & Женщины & Оба пола \\
\hline Общая численность, млн человек & & & \\
1939 & 29,6 & 32,6 & 62,2 \\
1959 & 15,7 & 26,8 & 42,5 \\
1979 & 9,4 & 20,0 & 29,4 \\
Убыль, млн человек за период & & & \\
1939-1959 & 13,9 & 5,8 & 19,7 \\
1959-1979 & 6,3 & 6,8 & 13,1 \\
1939-1979 & 20,3 & 12,6 & 32,8 \\
Убыль, \% к исходному году & & & 31,7 \\
за 1939-1959 & 47,1 & 17,8 & 30,8 \\
за 1959-1979 & 40,2 & 25,3 & 52,8 \\
за 1939-1979 & 68,4 & 38,6 & \\
Осталось в живых из общей численности, & & & 68,3 \\
зафиксированной переписью 1939 года, \% & 52,9 & 82,2 & 47,2 \\
к 1959 & 31,6 & 61,4 & \\
к 1979 &
\end{tabular}

В следующие 20 лет (между переписями 1959 и 1979 гг.) потери воевавших поколений от смертности были намного меньшими и не так разнились по полу. В абсолютном выражении убыль у женщин была даже большей, чем у мужчин, но это объясняется намного более высокой их исходной общей численностью в 1959 г. В относительном же выражении мужская часть воевавших поколений сократилась более чем на 40\%, тогда как женская - всего на четверть.

К моменту переписи населения 1979 г. исходная численность воевавших поколений, зафиксированная переписью 1939 г., сократилась более чем наполовину - но это лишь для обоих полов, взятых вместе. В то время как число женщин сократилось менее чем на 40\%, от мужской части воевавших поколений осталось меньше трети (таблица 3). 
Прошло еще немногим более 20 лет, в 2002 г. была проведена первая перепись населения постсоветской России, и она показала, что к этому времени из исходной численности воевавших поколений (62,2 млн человек в 1939 г.) осталась, приблизительно, одна десятая часть; 1,6 млн мужчин и 5 млн женщин (рисунок 3). Примерно в это время стали особенно громко и торжественно отмечать праздник Победы в той войне, на которой они воевали.

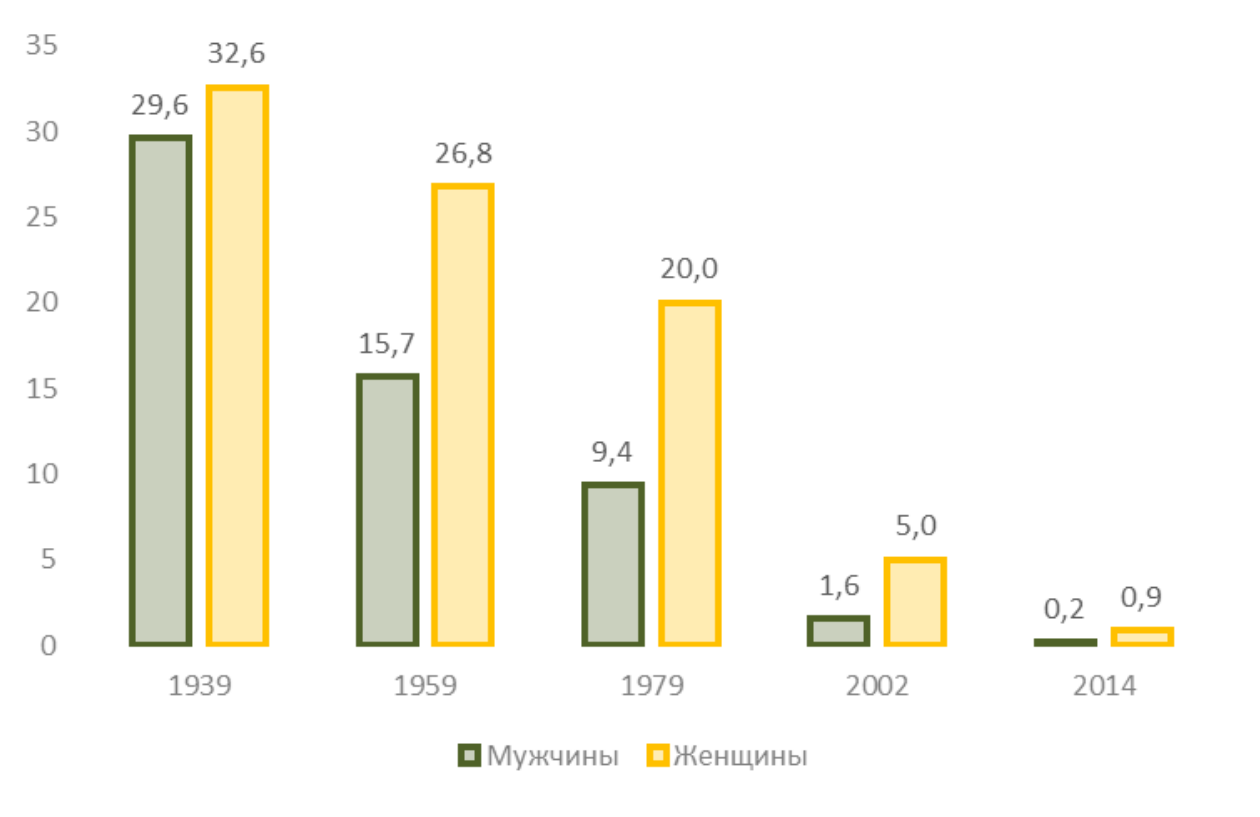

Рисунок 3. Уход воевавших поколений, млн человек

\section{СЛЕДЫ ВОЙНЫ НА ВОЗРАСТНОЙ ПИРАМИДЕ}

Гибель огромного числа людей, принадлежавших ко многим поколениям, очень сильно деформирует всю возрастную пирамиду. Но к этому добавляются еще и деформации, вызванные резким снижением рождаемости в военные годы. Обусловленные войной деформации не только сохраняются долгое время, перемещаясь с течением времени к верхней части пирамиды, но порождают новые деформации в ее нижней части, отзвуки войны, ее «эхо» звучат многие десятилетия. Война запустила цикл колебаний численности идущих одна за другой когорт, что придало циклический, волнообразный характер всему демографическому развитию России. Это хорошо видно на графиках, и это очень сильно затрагивает реальную жизнь многих десятков миллионов людей - их частную жизнь и экономическую и социальную жизнь всей страны.

Сопоставляя пирамиды 1939 и 1959 г. (рисунок 4), мы видим на пирамиде 1959 г. (помимо уже известной нам резко возросшей асимметрии мужской и женской частей пирамиды у воевавших поколений, а также переместившихся выше, но сохраняющихся выбоин - следствия падения рождаемости и повышения детской смертности в 1915-1921 и в 1932-1934 гг.) еще и новую огромную выбоину - след чрезвычайно низкой рождаемости 1941-1945 гг. 


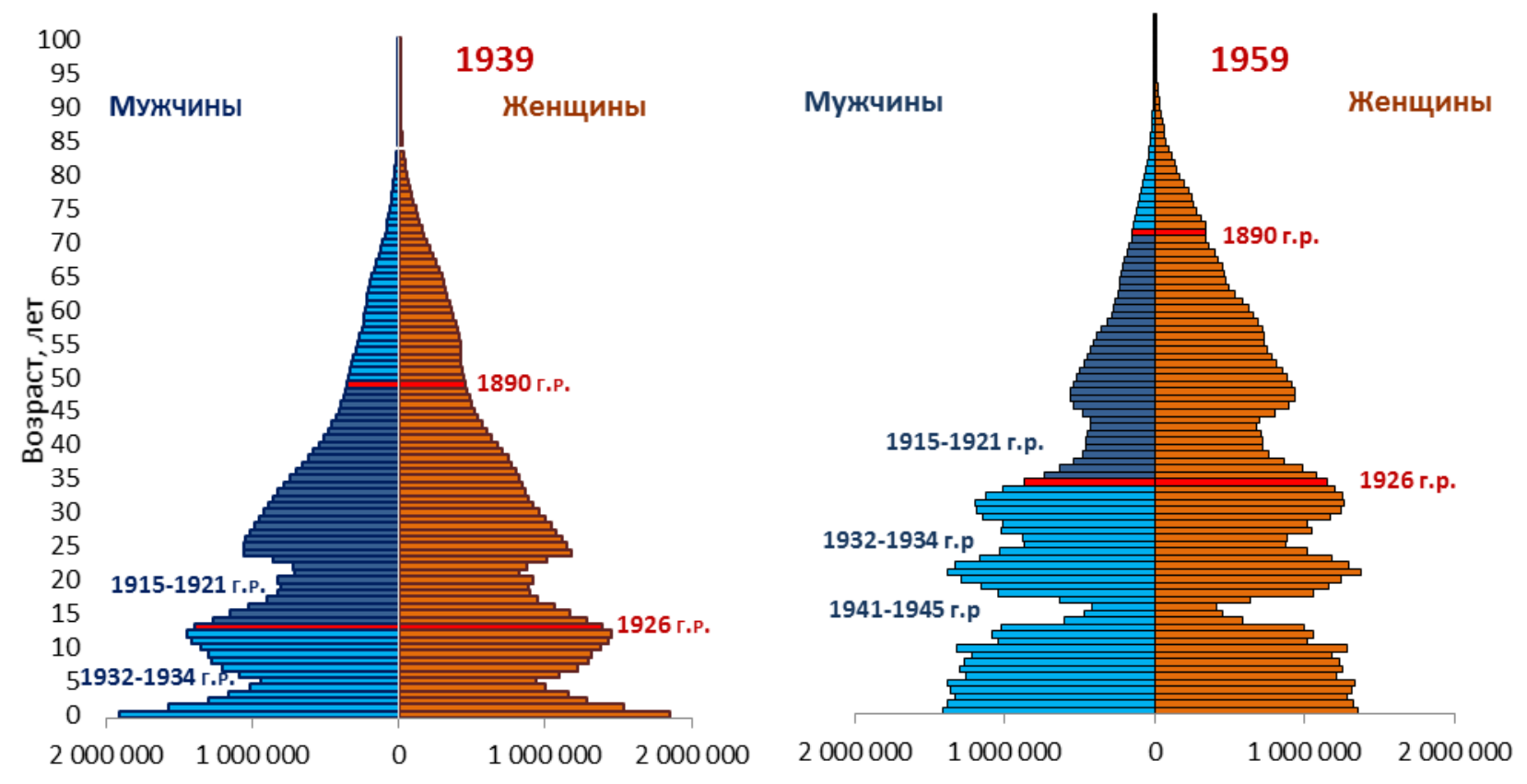

Рисунок 4. Возрастные пирамиды населения России 1939 и 1959 г., человек

Если теперь сдвинуться еще на тридцать лет вперед и сравнить пирамиду 1959 г. с пирамидой 1989 г., построенной на основе последней советской переписи населения (рисунок 5), мы увидим явное улучшение гендерного баланса в нижней части пирамиды, тогда как в верхней ее части, где теперь сосредоточены воевавшие поколения, сохраняется ярко выраженная гендерная асимметрия. Но что привлекает внимание, так это появление в нижней части возрастной пирамиды 1989 г. новой впадины - эха падения рождаемости в военные годы. Четверть века спустя после войны дети военных лет сами становились родителями, но их было мало, поэтому невелико было и число их детей - наиболее глубоким было падение в 1967-1969 гг., отстоящих на 25 лет от 1942-1945 гг.

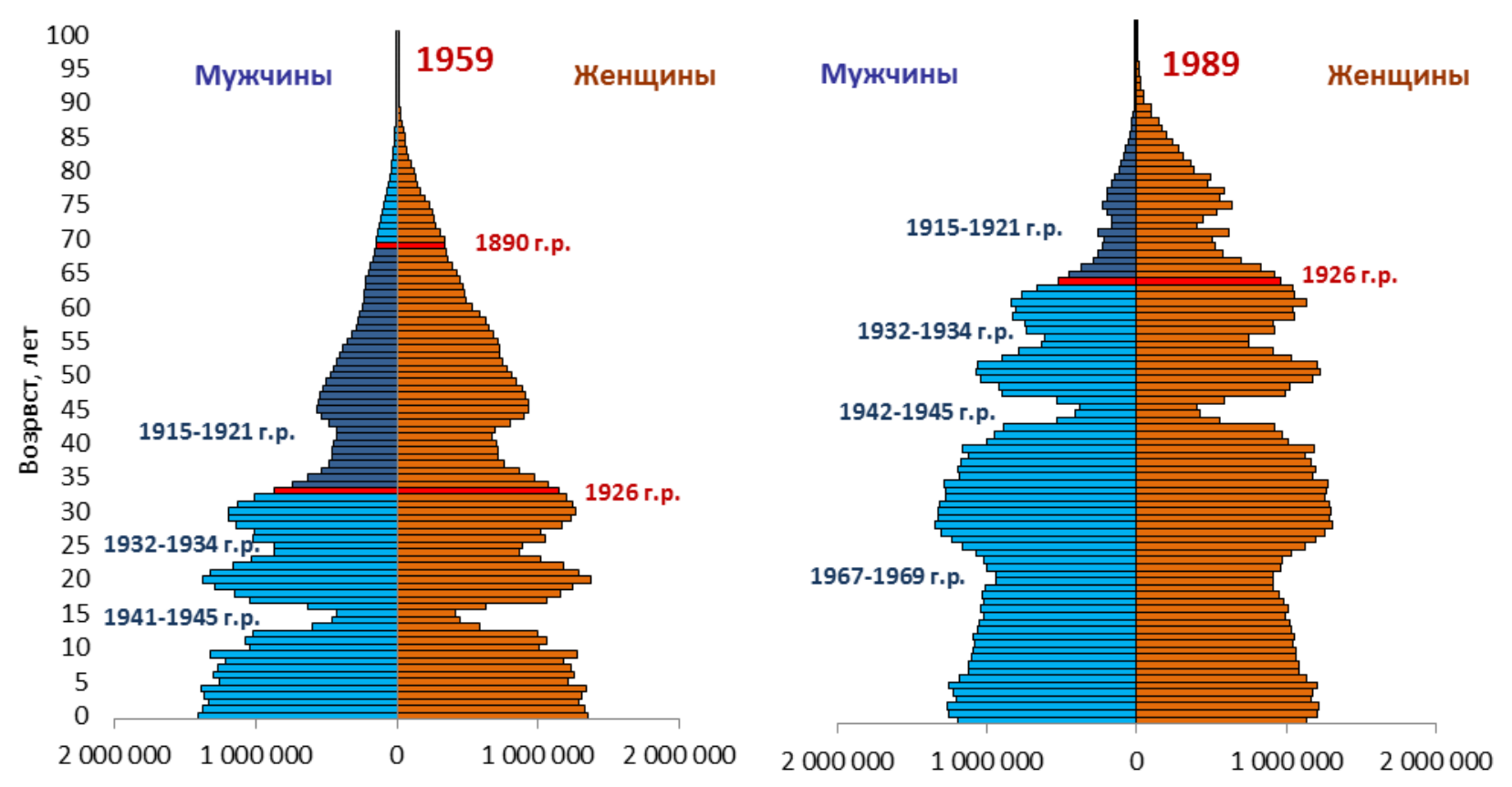

Рисунок 5. Возрастные пирамиды населения России 1959 и 1989 г., человек 
И, наконец, сравним возрастную пирамиду 1989 г. с пирамидой 2010 г., построенной по данным последней на данный момент Всероссийской переписи населения (рисунок 6). Красная линия 1926 г. рождения, отделяющая воевавшие поколения от не воевавших, приближается к вершине пирамиды, тем, кто родился в 1926 г., в 2010 г. исполнилось 84 года. Но след войны прочитывается в новой впадине в нижней части пирамиды - очередном отголоске войны. Четверть века спустя после первого послевоенного снижения числа родившихся у детей войны родителями становятся дети их детей, а их тоже, как мы видели, было сравнительно немного, так что нового сокращения числа рождений следовало ожидать. Судя по пирамиде 1989 г., оно уже наметилось в конце 80-х годов. Но, повидимому, падение числа рождений в 1990-е годы, которое в любом случае было неизбежно, усилилось под воздействием социально-политических, экономических и даже демографических изменений, происходивших в это время, и оказалось более глубоким, чем можно было ожидать.

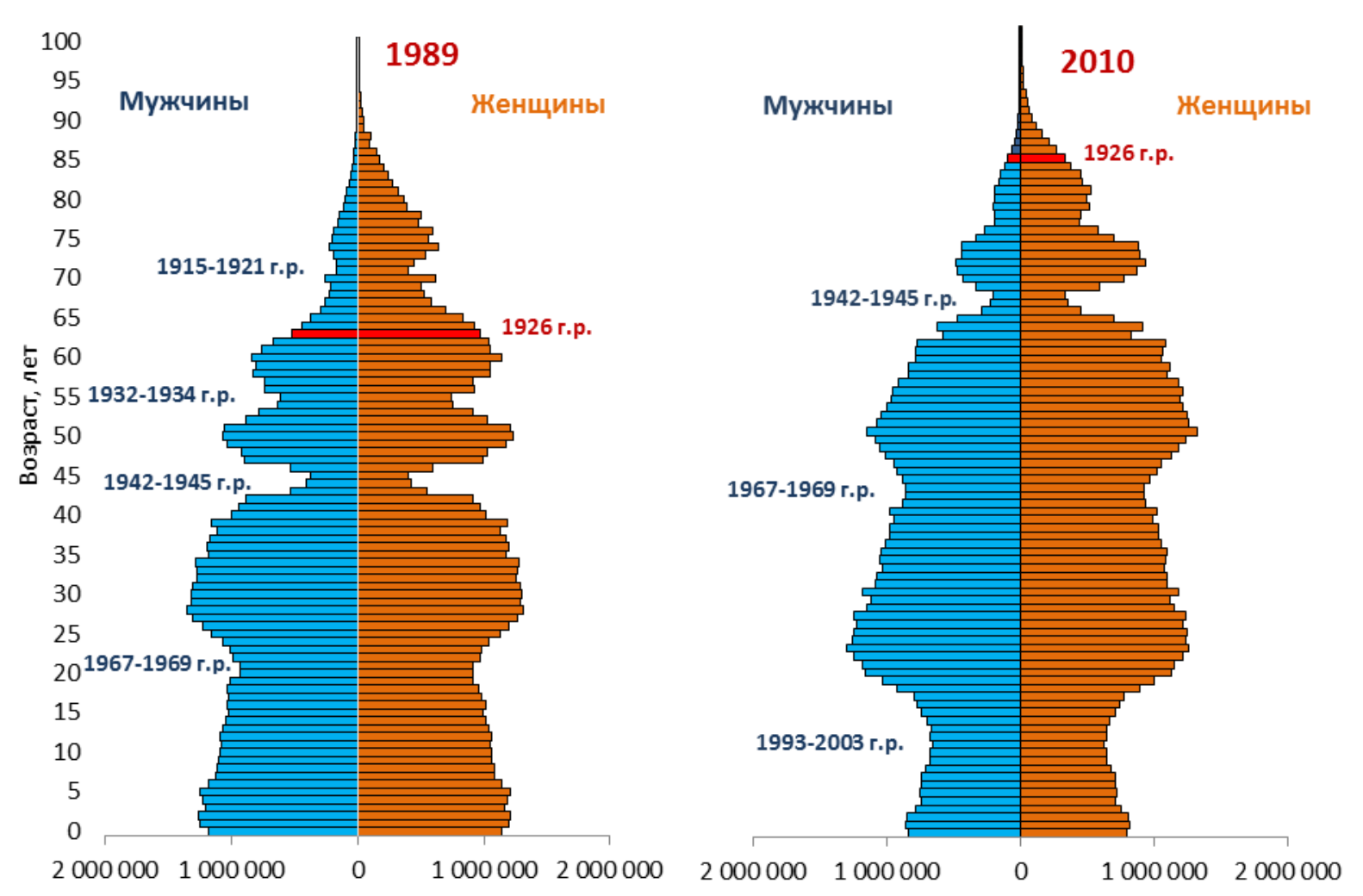

Рисунок 6. Возрастные пирамиды населения России 1989 и 2010 г., человек

\section{ГЕНДЕРНАЯ АСИММЕТРИЯ}

На протяжении почти всего XX века Россия жила в условиях неестественной гендерной асимметрии, которая возникла после Первой мировой и Гражданской войн и резко усилилась после Второй мировой войны.

Значительный женский перевес характерен для всех воевавших стран, но в России он особенно велик даже по сравнению с Германией, также понесшей огромные потери и в 
Первой, и особенно, конечно, во Второй мировой войне. Не удивительно, что в послевоенных возрастных пирамидах обеих стран есть много общего (рисунок 7).
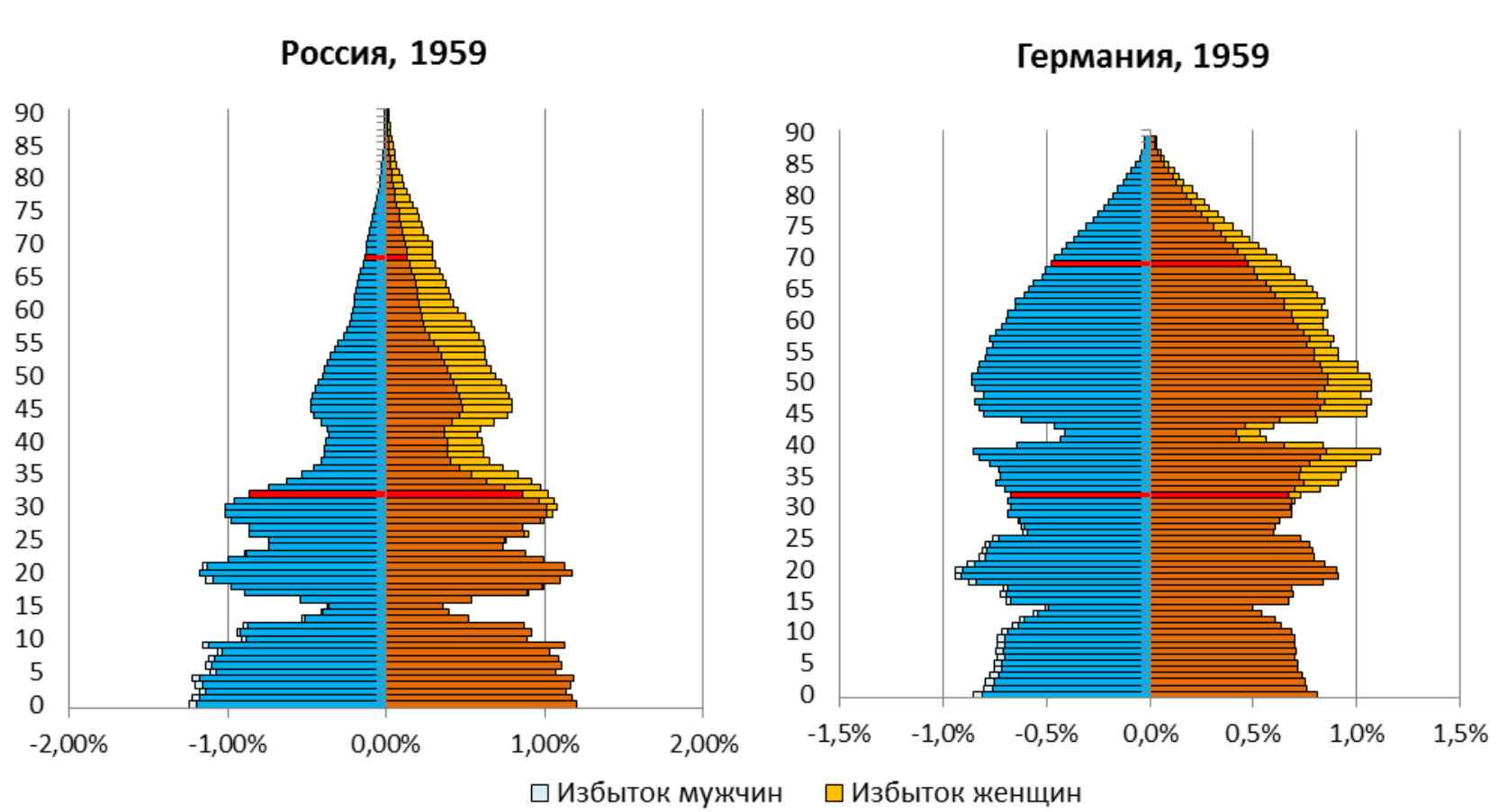

Рисунок 7. Возрастные пирамиды населения России и Германии в 1959 г., \%

Источник для Германии: [Statistisches Bundesamt 2016].

Тем не менее при более внимательном рассмотрении оказывается, что женский перевес в воевавших поколениях в России несопоставимо больше, чем в Германии. Он особенно велик в поколениях, воевавших в войнах второго десятилетия XX века (родившихся примерно до 1905 г.), что объяснимо, так как в отличие от Германии Россия несла потери не только в Первой мировой, но и в Гражданской войне. Тем не менее он значителен также и в более молодых поколениях (рисунки 8 и 9), что говорит и о более значительных потерях России во Второй мировой войне.

Военные потери - не единственный источник нарушения равновесия полов в населении, вторая его причина - более высокая смертность мужчин, в России намного превосходящая женскую смертность. Но все же на протяжении по крайней мере пяти десятилетий после начала войны главным источником гендерного дисбаланса были военные потери. По мере того, как воевавшие поколения переходили в старшие возраста, туда же смещалось и неравновесие полов, у не воевавших поколений половая пропорция была намного более благоприятной. 


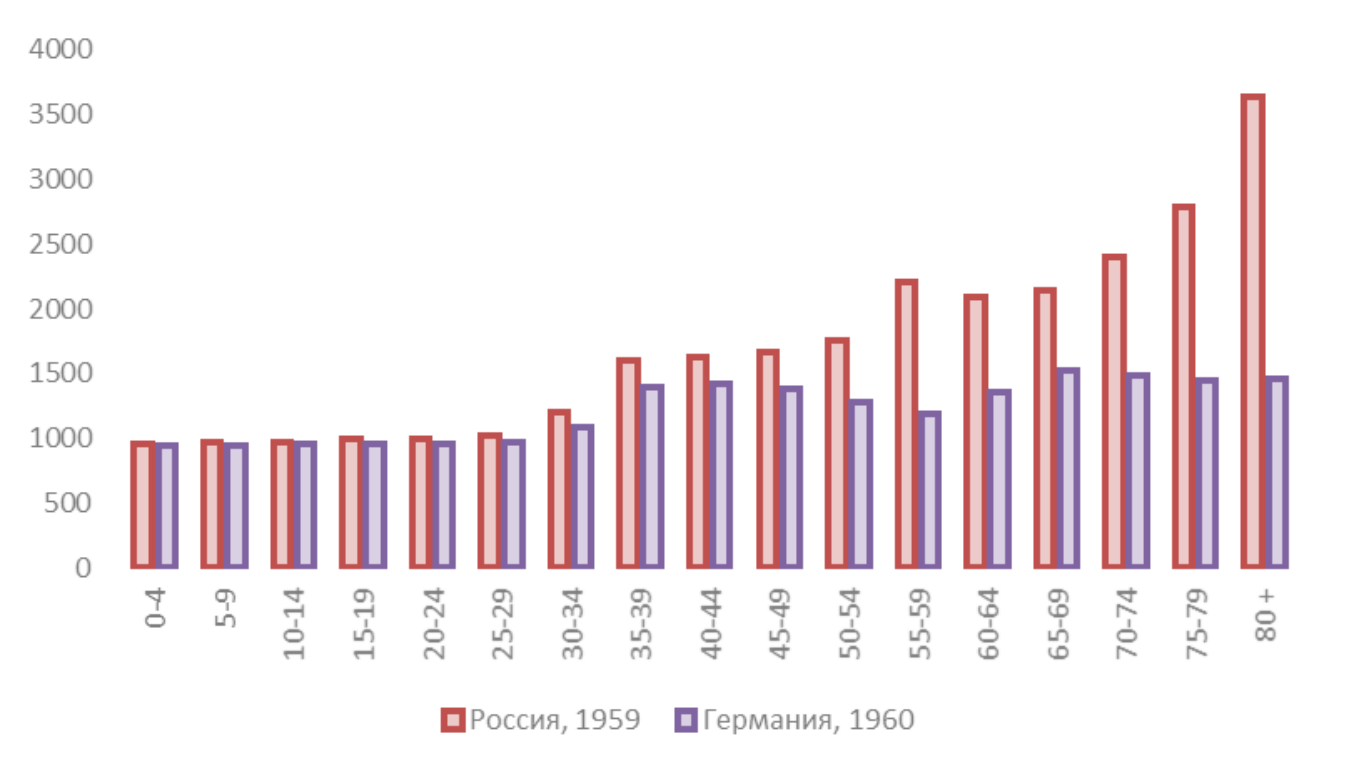

Рисунок 8. Число женщин на 1000 мужчин в России и Германии в 1959 г.

Источник для Германии: [Statistisches Bundesamt 2016].

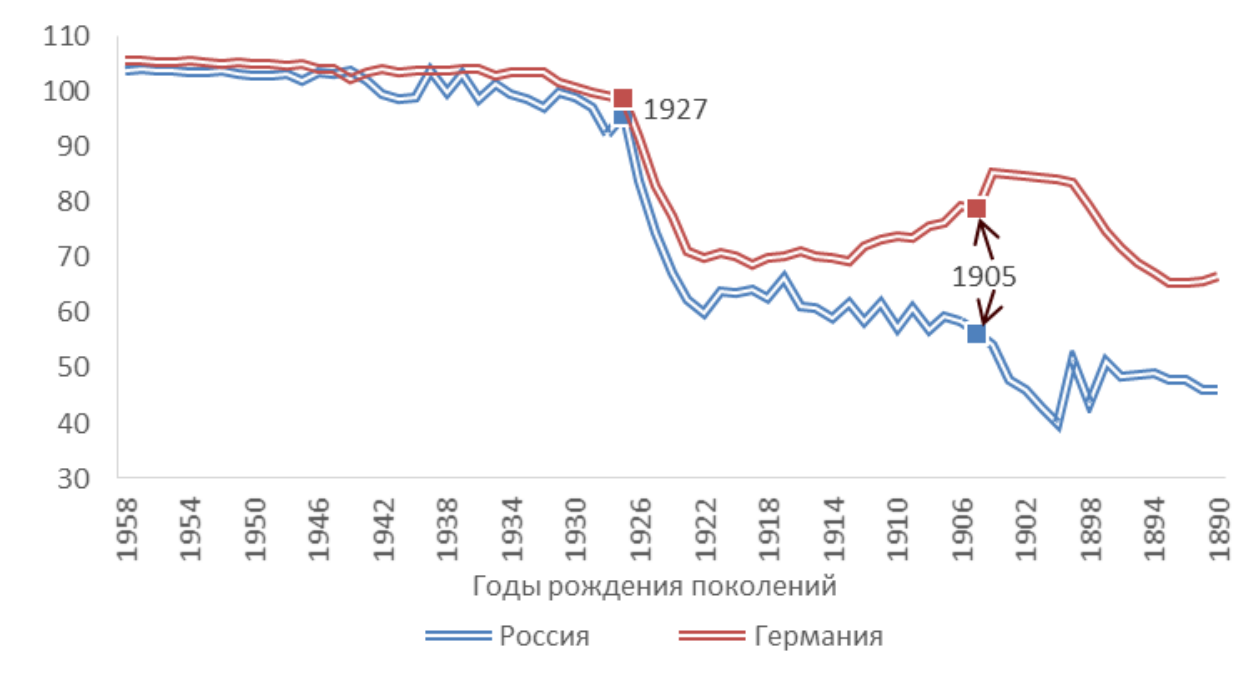

Рисунок 9. Число женщин на 1000 мужчин в воевавших и не воевавших поколениях в России и Германии в 1959 г.

Источник для Германии: [Statistisches Bundesamt 2016].

По данным переписи населения 1959 г. женский перевес заметен уже начиная с возрастной группы 30-34 года, в 1970 г. - начиная с группы 40-44 года, в 1979 г. - с группы 50-54 года и т.д. (рисунок 10).

Еще во время переписи населения 1989 г. основной вклад в общий женский перевес в населении России вносили воевавшие поколения - за счет огромных военных потерь, но также и за счет более высокой мужской смертности в послевоенное время. Так как эти поколения становились все менее многочисленными, снижался и их вклад в женский перевес во всем населении, который благодаря этому уменьшался. Изменение положения зафиксировала только перепись 2002 г.: вклад воевавших поколений значительно сократился, а женский перевес вырос (рисунок 11). Это уже не связано с последствиями 
войны, а объясняется значительным превышением мужской смертности над женской. До 1992 г., несмотря на более высокую смертность мужчин, абсолютное число мужских смертей было меньше числа женских - следствие меньшей численности мужского населения. С 1992 г. положение изменилось на противоположное: даже несмотря на меньшую численность мужского населения, ежегодно регистрируется большее число мужских смертей. За 10 лет с 1982 по 1991 г. число умерших женщин превысило число умерших мужчин на 597,9 тыс. За 10 лет с 1992 по 2001 г. - напротив, умерло на 927,1 тыс. больше мужчин, чем женщин, за следующее десятилетие с 2002 по 2011 г. - на 1292,7 тыс. больше. Понятно, что это не могло не отразиться на соотношении полов в населении. Большое значение имеет также процесс демографического старения, в результате которого в населении нарастает доля старших возрастных групп, для которых характерно менее благоприятное соотношение полов.

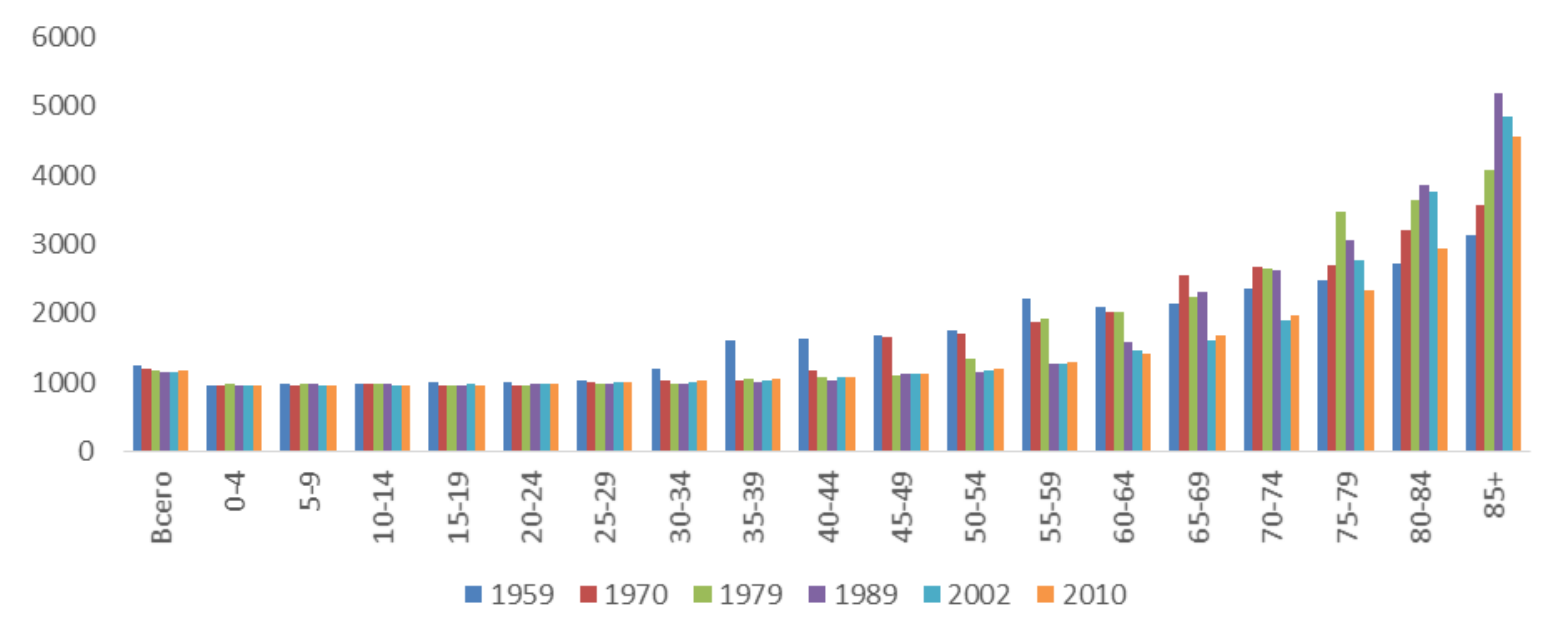

\section{Рисунок 10. Число женщин на 1000 мужчин в России по данным послевоенных переписей населения}

Но все это относится уже к самым последним десятилетиям, большая же часть ХX века прошла под знаком гендерного дисбаланса, обусловленного военными потерями.

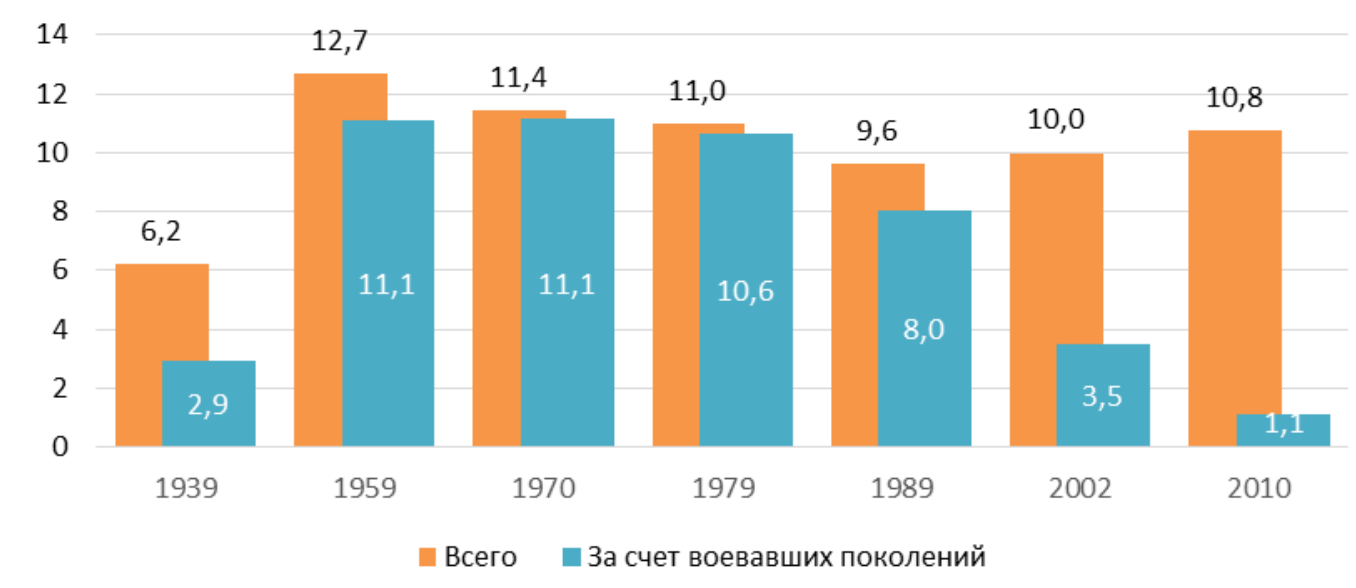

Рисунок 11. Женский перевес в России по данным переписей населения 1939-2010 гг., млн человек 


\section{ВОЙНА И СЕМЬЯ}

Небывалые потери мужского населения лишили многих женщин потенциальных брачных партнеров, что привело к значительному увеличению доли женщин, никогда не состоявших в браке. О матримониальной судьбе женщин воевавших поколений, начиная с поколений 1900 г. рождения, позволяют судить ретроспективные оценки, выполненные С. Захаровым на основе данных микропереписи 1994 г., учитывавшей не только официально зарегистрированные, но и фактические браки (рисунок 12). Если у поколений женщин, не участвовавших в войне и достигших к 1994 г. возраста 50 лет и старше, т.е. в основном уже вышедших за пределы возраста заключения первых браков, в замужестве на протяжении жизни состояло 95-96\% женщин, то у воевавших поколений - 93,5\% и менее, причем эта доля резко падает у самых молодых воевавших поколений, у которых до 1941 г. процесс формирования брачных пар еще не набрал силу.

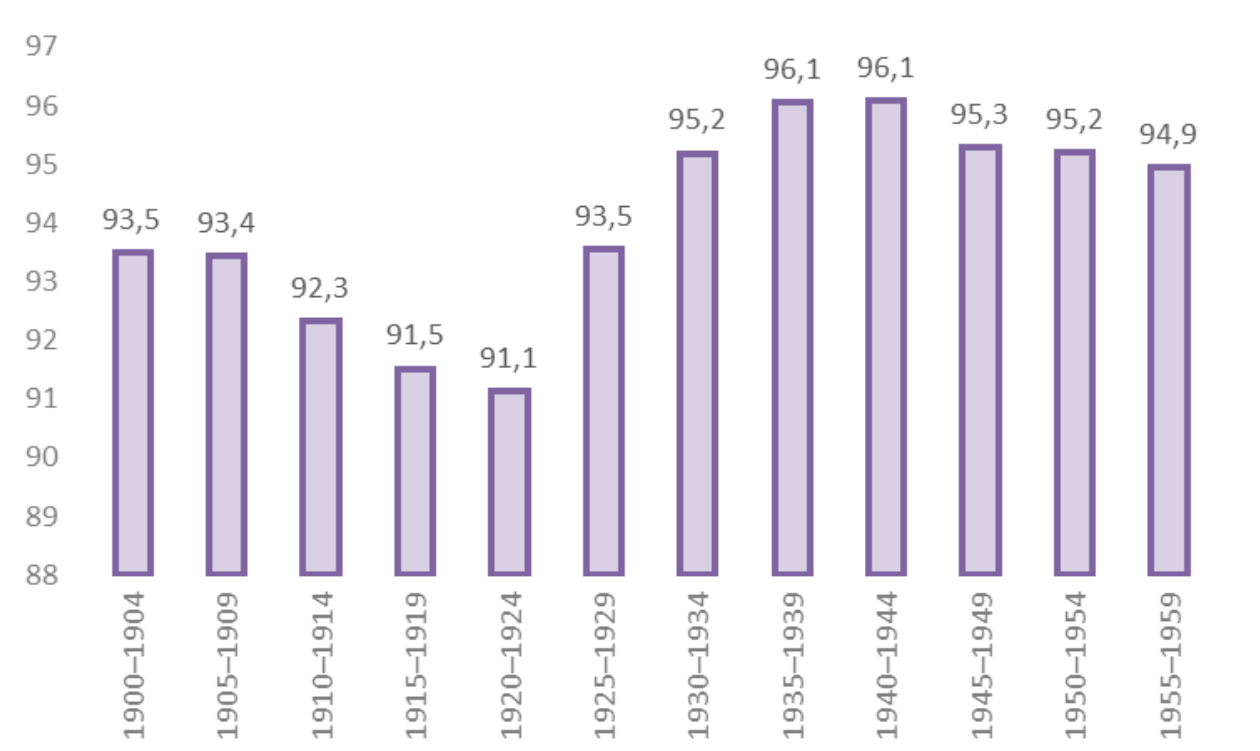

\section{Рисунок 12. Доля женщин, когда-либо вступивших в первый брак, в воевавших и не воевавших поколениях, \%}

Источник: [Демографическая модернизаиия России 2006: 113-114].

Но влияние войны на брачное состояние населения отнюдь не ограничивается трудностями для женщин нахождения брачного партера в условиях дефицита женихов. Это влияние гораздо глубже и многостороннее. Война дестабилизировала брачную и семейную структуры населения, разрушила многие, часто едва начавшиеся браки, усилила конкуренцию на брачном рынке, что имело свои следствием рост числа разводов. Полностью оценить все эти последствия сегодня едва ли возможно.

В стране осталось огромное количество вдов, однако сколько их было неизвестно, и помочь в оценке их числа не может и перепись населения 1959 г. Хотя международные стандарты проведения переписей всегда предусматривали вопросы, позволяющие выделить четыре категории брачного состояния, включая вдовых, и соответствующие вопросы задавались в России уже при проведении первой всеобщей переписи 1897 г. и первой всесоюзной переписи 1926 г, статистика сталинского времени считала такие 
вопросы не стоящими внимания, и, начиная с переписи 1937 г. и кончая переписью 1970 г., советские переписи (значит, и перепись 1959 г.) позволяли разграничить только две совокупности: состоящих и не состоящих в браке в момент переписи. Соответственно, никакой информации о числе вдов в них не было, впервые вопрос обо всех брачных состояниях вновь появился только в программе советской переписи 1979 г. [Вишневский, Захаров 2010: 13].

Не было никакой информации и о числе послевоенных сирот, оказавшихся без одного или без обоих родителей, равно как и о числе инвалидов войны, которое было огромным. Вдовы, сироты и инвалиды войны всегда присутствовали в пропагандистской риторике, но никто не знал, сколько их было, и никто не пытался этого узнать. Вероятно, в органах социального обеспечения, выплачивавших пособия вдовам и детям погибших на фронте, инвалидам войны, какая-то статистика все же существовала, однако она никогда не обнародовалась и не присутствовала в общественном дискурсе. В научной литературе можно встретить лишь самые общие упоминания вроде того, что «в поколениях женщин, которым в 1941 г. было 17-25 лет и которые наиболее пострадали во время войны, ...было много вдов и не вышедших замуж» [Поляков, Жиромская, Араловец 2004], но не более того.

В самом деле, перепись 1959 г. указала лишь на чрезвычайно низкую по сравнению с предыдущими переписями долю замужних среди женщин в возрасте от 40 до 59 лет (т.е. тех, кому в 1939 г. было от 20 до 39 лет; рисунок 13) - и это, конечно, результат совместного действия овдовения, прекращения брака разводом и невступления в брак.

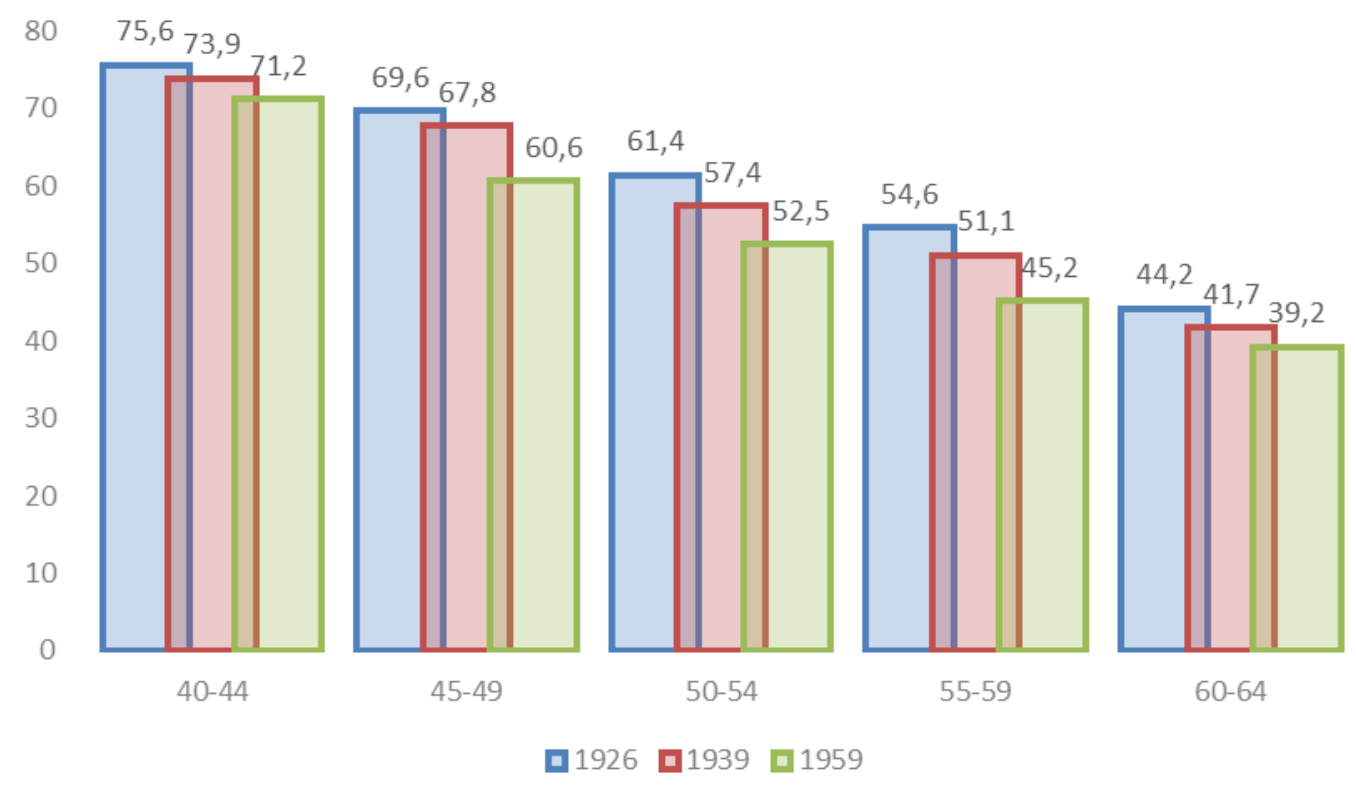

\section{Рисунок 13. Число замужних на 100 женщин соответствующей возрастной группы по переписям 1926, 1939 и 1959 гг.}

В весьма значительной степени все эти факторы - следствие послевоенных деформаций брачного рынка и возникающей на нем конкуренции из-за нехватки мужчин. «Вдовство многих женщин, потерявших мужей на войне, в силу половой диспропорции длится всю последующую жизнь... В условиях значительного численного преобладания женщин существенно ослабевает прочность браков, и повышение числа разводов по 
инициативе мужчин сокращает длительность брака. При наличии диспропорции полов происходит процесс стихийного перераспределения брачных партнеров, причем не только по возрасту, но и по брачному состоянию. Это перераспределение совершается за счет повышенной брачности женщин со сверстниками, с мужчинами более молодыми, поколения которых война не затронула, а также с разведенными и вдовцами» [Ильина 1977: $55]$.

Государство пыталось противодействовать неизбежным в сложившейся ситуации процессам единственным доступным ему способом - ужесточением законодательства в области брака и семьи. 8 июля 1944 г., меньше чем за год до конца войны, был принят Указ Президиума Верховного совета СССР, резко изменивший существовавшие до этого относительно либеральные советские правовые нормы в области брака и семьи. Указ назывался очень красиво: «Об увеличении государственной помощи беременным женщинам, многодетным и одиноким матерям, усилении охраны материнства и детства, об установлении почетного звания Мать-героиня и учреждении ордена Материнская слава и медали Медаль материнства» [Указ 1944].

Ничто в названии указа не говорило о содержащемся в нем разделе V «Об изменениях в законах о браке, семье и опеке». Между тем именно в этом разделе устанавливалось условие, что «только зарегистрированный брак порождает права и обязанности супругов», и отменялось «существующее право обращения матери в суд с иском об установлении отцовства и о взыскании алиментов на содержание ребенка, родившегося от лица, с которым она не состоит в зарегистрированном браке». Устанавливалось, что при регистрации рождения ребенка от матери, не состоящей в зарегистрированном браке, ребенок записывается по фамилии матери с присвоением ему отчества по указанию матери. Вводилось правило обязательной записи зарегистрированного брака в паспортах, существенно усложнялась процедура развода. Указ также подкреплял уже имевшуюся норму поручением «органам прокуратуры, в соответствии с действующим уголовным законодательством, привлекать к ответственности виновных в незаконном производстве абортов, в понуждении женщин к производству аборта».

Содержащиеся в указе нововведения мотивировались тем, что «забота о детях и матерях и об укреплении семьи всегда являлась одной из важнейших задач советского государства», но на деле государство недвусмысленно давало понять женщинам, оставшимся без мужчин, что это - $u x$ проблема. В каком-то смысле указ сыграл роль ширмы, сделавшей недоступными для государственной статистики и укрывшей от общественного мнения все явления, о которых не хотели говорить вслух. Число регистрируемых разводов действительно сократилось, но это не значит, что браки перестали распадаться без регистрации. О числе загнанных в подполье фактических разводов ничего не было известно, но когда в 1965 г. процедура развода была упрощена, число разводов за один год выросло в 1,8 раза (с 360 до 646 тыс.) [ЦСУ СССР 1975: 150]. Затруднение процедуры развода усложнило и заключение повторных браков, но это означает лишь то, что значительная их часть перестала фиксироваться статистикой, так что их число тоже неизвестно. 
Никакие указы не могли изменить сложившиеся после войны демографические реалии. Огромное число женщин оказались обреченными на одиночество, а детей - на безотцовщину. Широкое распространение после войны получила внебрачная рождаемость, в СССР резко выросло число одиноких матерей, по имеющимся оценкам, в 1945 г. их было 281,7 тыс., а в 1957 г. - 3312 тыс. [Харчев 1979: 168-169]. Около четверти всех рождений в 1945 г. были внебрачными, и даже 10 лет спустя - почти 17\%. Характерно, что эта доля в сельском населении была выше, чем в городском (таблица 4).

Таблица 4. Доля внебрачных рождений в общем числе рождений, \%

\begin{tabular}{c|c|c}
\hline Год & Все население & В том числе сельское \\
\hline 1945 & 24,4 & $\ldots$ \\
1955 & 16,9 & 14,5 \\
1965 & 13,0 & 13,7 \\
1975 & 10,7 & \\
\hline
\end{tabular}

Источник: [Иванова, Михеева 1998: Табл. 3].

В соответствии с указом 1944 г. в свидетельстве о рождении детей вне зарегистрированного брака вместо сведений об отце в обязательном порядке ставился прочерк. За время действия этого «гуманного» правила (с 1945 по 1968 г.) прочерк в паспорте получили более 15 млн детей [Тольц 2014: 161]. Но общество не должно было ничего знать об этом. В архивах сохранилось письмо начальника ЦСУ СССР в ЦК КПСС.

\section{«В ЦК КПСС}

$$
\text { 14.01.1970 }
$$

...В «Литературной газете» 7.01.1970 Урланис в статье «Безотцовщина» приводит данные о детях у матерей, не состоящих в зарегистрированном браке, которые не публикуются в открытой печати.... Буржуазная пропаганда может использовать [это] во враждебных целях, т.к. в буржуазных странах таких детей обычно относят к незаконнорожденным... ЦСУ просит обратить внимание редакции «Литературной газеты» на недопустимость публикации данных, не подлежащих опубликованию в открытой печати...

Старовский» ${ }^{3}$.

\section{ВОЙНА И РОЖДАЕМОСТЬ}

Выше уже говорилось, что война запустила цикл колебаний численности идущих одна за другой когорт, что, в частности, очень сильно сказалось на рождаемости. Во время войны резко снизилось число рождений, а значит и число тех, кому предстояло примерно через два десятилетия стать родителями новых поколений детей, причем это снижение затухающим эхом отзывается еще несколько раз с интервалом приблизительно в 25 лет.

\footnotetext{
${ }^{3}$ РГАЭ. Ф.1562. Оп. 47. Ед.хр. 35. Докладные записки в ЦК КПСС и СМ СССР по вопросам статистики населения и здравоохранения за 1970 год. Лист 1.
} 
Падение числа рождений в 1942-1945 гг., особенно сильное в 1943-1944 гг., было уже не первым в XX веке, но оно было намного глубже предыдущих. В 1943 г., когда это падение достигло дна, родилось почти втрое меньше детей, чем в годы предыдущих минимумов - 1917 и 1934. Послевоенный же подъем рождаемости позволил общему числу рождений лишь ненадолго вернуться к уровню этих двух минимумов (рисунок 14).



\section{Рисунок 14. Число рождений в России в 1900-2015 годах, млн}

Источники: [Демографическая модернизация России 2006:184; Демографический ежегодник России 2015: табл. 2.1].

Колебаниям числа рождений соответствовали порожденные ими колебания числа женщин материнских возрастов. На рисунке 15 видно, что, хотя эти колебания постепенно затухают, они все еще остаются очень большими. Примерно $80 \%$ всех детей рожают обычно женщины в возрасте 20-34 года, изменение их числа хотя и не в полной, но в решающей степени определяют динамику материнского потенциала страны. Между 1984 и 1998 гг. число женщин этой возрастной группы сократилось на 3 млн, продержалось на этом уровне 3 года, а затем между 1998 и 2010 гг. снова выросло на 2,2 млн, что в значительной степени обусловило рост числа рождений в «нулевые» годы. Но затем начался новый цикл снижения числа женщин материнских возрастов - третий после войны. Кажется, что война была очень давно, но на самом деле мы находимся всего лишь где-то в середине третьего цикла - вблизи точки перегиба, когда число рождений снова начнет сокращаться. 


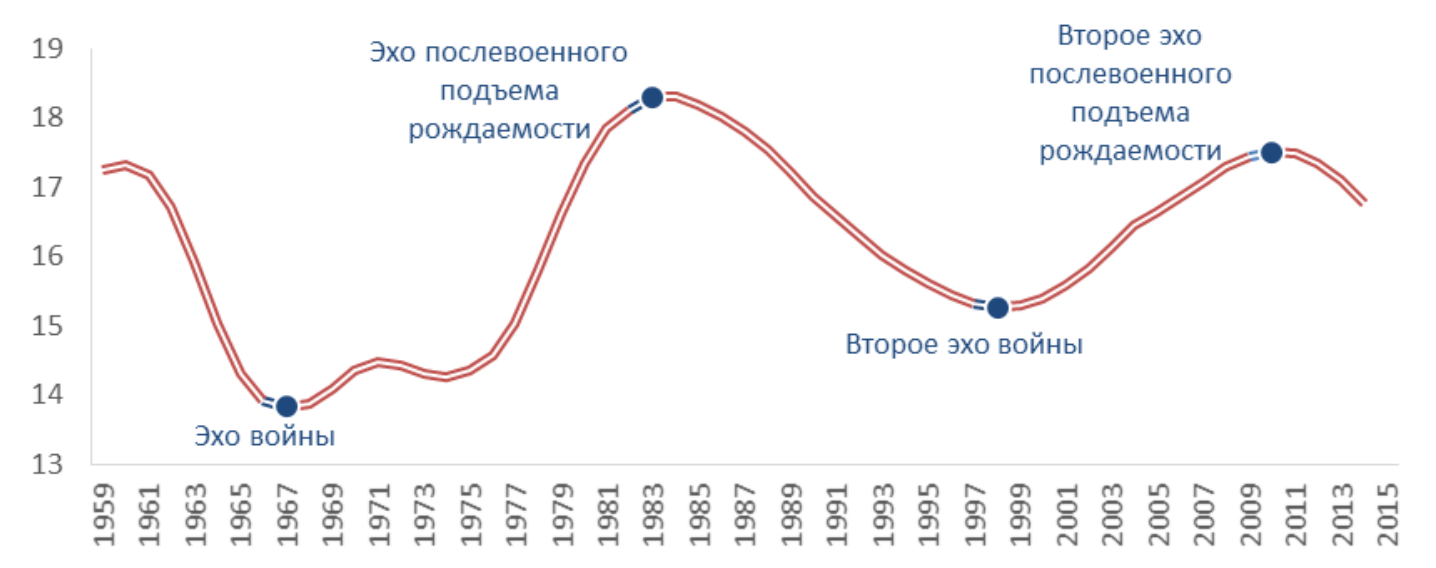

\section{Рисунок 15. Число женщин в возрасте 20-34 года, млн}

Источник: Демографический ежегодник России за разные годы.

Насколько сильно влияют эти колебания на общее число рождений, которое зависит и от других причин?

Учитывая определяющий вклад в рождаемость матерей в возрасте 20-34 года, в первом приближении и с определенной степенью условности уровень рождаемости можно измерять числом рождений только у женщин 20-34 лет на 1000 женщин этой возрастной группы. В демографии применяются намного более изощренные измерители, но для грубых прикидок можно воспользоваться и таким показателем, относящимся к категории «специальных коэффициентов рождаемости». Его изменения на протяжении длительного времени свидетельствуют о снижении рождаемости в России. В 1984 г., когда число женщин в возрасте 20-34 года достигло своего исторического максимума (18,3 млн), в расчете на 1000 женщин этой возрастной группы у женщин всех возрастов рождалось 132 ребенка, у женщин именно этой возрастной группы - 111 детей. Это существенно ниже, чем, например, в 1960 г., когда эти показатели составляли соответственно 162 и 130, хотя намного выше, чем в последующие годы, когда они достигли очень низких значений (79 и 66 на 1000 в 1999 г.). Но какое-то время после 1984 г. эти коэффициенты еще росли, противодействуя негативному влиянию начавшегося снижения материнского потенциала, и число рождений до 1987 г. увеличивалось. Однако затем сокращение числа женщин в наиболее эффективных материнских возрастах соединилось со снижением рождаемости, и под влиянием этих двух факторов число рождений в России стало сокращаться. Позднее, после 1999 г., оба фактора стали действовать в противоположном направлении, способствуя росту числа рождений.

Можно попытаться разделить вклад в эти изменения указанных факторов собственно изменений рождаемости, обусловленных текущими социальными и экономическими причинами и мерами политики, и изменений числа потенциальных матерей на нисходящей и восходящей ветвях волн запущенных войной колебаний. На рисунке 16 представлены фактическое (по данным Росстата) изменение числа рождений после 1984 г. под воздействием обоих факторов и его гипотетическое изменение при условии, что колебания числа женщин в возрасте 20-34 года после 1984 г. прекратились, оно оставалось постоянным, а изменения числа рождений на 1000 женщин этой возрастной группы соответствовали фактическим. Как видим, изменение гипотетического числа 
рождений все равно имело бы ту же направленность, что и фактического, но падение абсолютного числа рождений было бы меньшим. При сделанном допущении за три десятилетия после 1984 г. (1985-2014 гг.) в России родилось бы 55,5 млн детей, в том числе 45 млн - у женщин в возрасте 20-34 года. На самом же деле родилось 50,7 млн и 41,2 млн, т.е. соответственно на 4,8 и на 3,8 млн меньше. С учетом того, что за весь тридцатилетий период в среднем за год рождалось 1,8 млн детей, 4,8 млн несостоявшихся рождений довольно значительная величина.

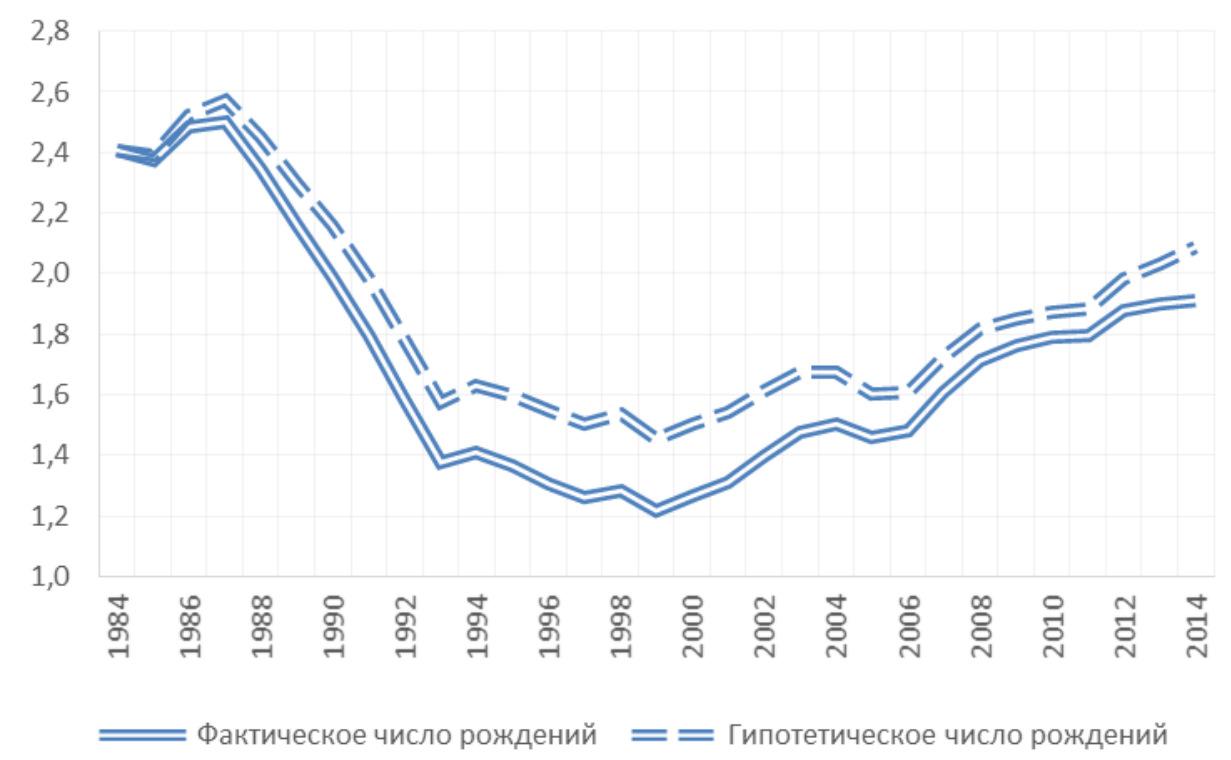

\section{Рисунок 16. Фактическое и гипотетическое число рождений при условии неизменности числа женщин 20-34 лет на уровне 1984 г., млн}

На рисунке 16 обращает на себя внимание также и то, что разрыв между двумя кривыми вначале нарастает (до 1999 г.), а затем сокращается. Это объясняется тем, что траектория пунктирной кривой (гипотетического числа рождений) определяется действием только одного фактора - изменений собственно рождаемости, а траектория сплошной кривой (фактического числа рождений) - также еще и влиянием изменения числа женщин. До 1999 г. это изменение содействовало снижению числа рождений, а после этого противодействовало ему.

\section{ВОЙНА И ЕСТЕСТВЕННЫЙ ПРИРОСТ НАСЕЛЕНИЯ}

В 1992 г. естественный прирост населения России впервые со времен войны стал отрицательным. В 1990-е - 2000-е годы отрицательный естественный прирост населения наблюдался во многих странах Европы, особенно Восточной. Но первой европейской страной, где число смертей превысило число рождений (на 20 лет раньше, чем в России), была Германия. В России же тогда естественный прирост населения превышал 6\%, и казалось, что положение здесь было намного лучше. Однако это видимое благополучие плохо сочеталось с тем, что рождаемость в России уже в 1964 г. упала ниже уровня, обеспечивающего простое воспроизводство населения (нетто-коэффициент воспроизводства опустился ниже единицы), и с тех пор и по сегодняшний день, за 
исключением трех «горбачевских» лет (1986-1988 гг.), нетто-коэффициент воспроизводства населения России находится ниже этого уровня. В Германии же на протяжении всех 1960-х годов нетто-коэффициент превышал единицу и опустился ниже нее лишь в 1970 г. (рисунок 17).

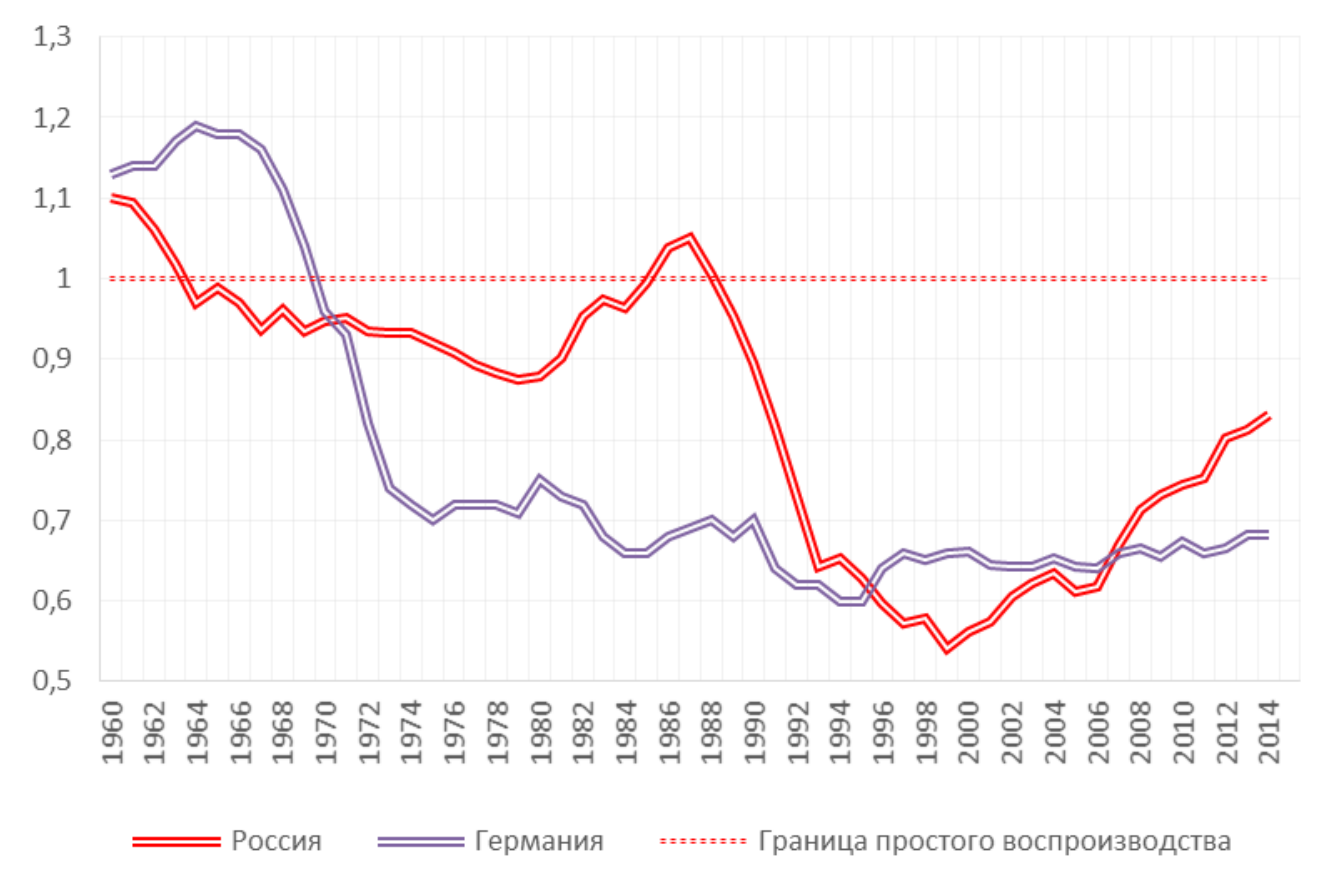

\section{Рисунок 17. Нетто-коэффициент воспроизводства населения России и Германии}

Источник: [База данных Демоскопа Weekly]. URL: http://www.demoscope.ru/weekly/ssp/sng_rni.php (дата обращения: 22.06.2016).

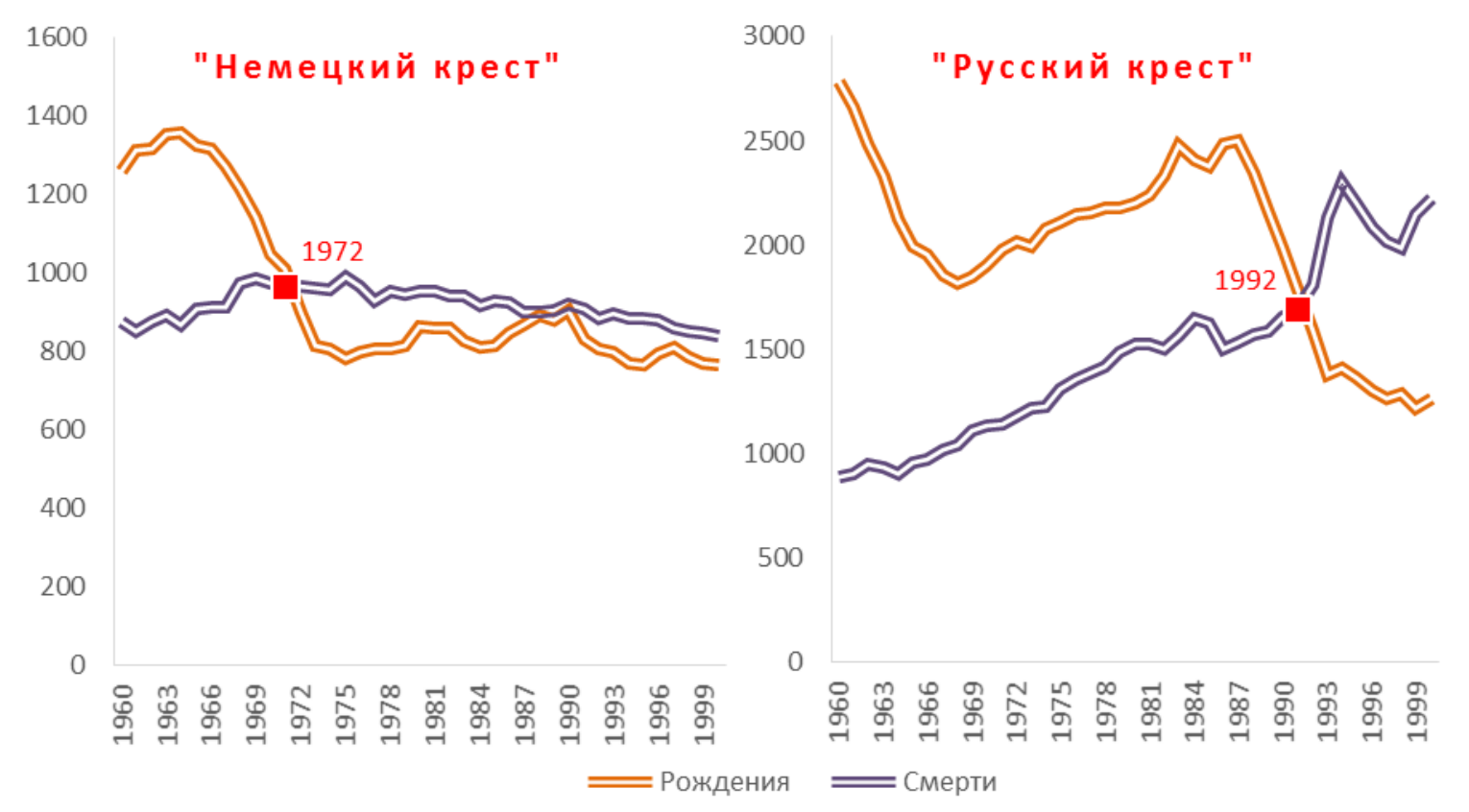

\section{Рисунок 18. Естественный прирост населения России и Германии, тыс. человек}

Источник: База данных Демоскопа Weekly. URL: http://demoscope.ru/weekly/app/app4003.php (дата обращения: 22.06.2016). 
Длительное сохранение нетто-коэффициента воспроизводства на уровне ниже единицы предопределяло переход к отрицательному естественному приросту населения, но он появился в России только в 1992 г., на 20 лет позже, чем в Германии (рисунок 18).

Объяснение этого парадокса кроется в особенностях послевоенной половозрастной структуры населения России, в том числе и таких, которые, способствуя улучшению текущих показателей, отнюдь не свидетельствовали о действительном благополучии. Естественный прирост - это разница между числом родившихся и числом умерших. В 1972 году, когда в Германии впервые появилась естественная убыль населения, в России родилось 2014,6 тыс. детей, а общее число смертей составило 1181,8 тыс., естественный прирост составил почти 833 тыс. человек. При той же численности населения, которая была в России в 1972 году (131,7 млн человек), и при тех же возрастных показателях рождаемости и смертности, которые в действительности наблюдались в России в этом году, но при половозрастных пропорциях населения Германии, картина была бы совсем другой. Естественный прирост был бы не 832,8 тыс. человек, а всего 18,5 тыс., а в следующем, 1973 году он, как и в Германии, стал бы отрицательным (таблица 5, рисунок 19).

Таблица 5. Естественный прирост населения России в 1972 г. фактический и при половозрастной структуре населения Германии, тыс. человек

\begin{tabular}{l|c|c}
\hline & Фактически & При структуре населения Германии \\
\hline Число рождений & 2014,6 & 1768,2 \\
Число смертей & & \\
Мужчины & 579,2 & 954,4 \\
Женщины & 602,6 & 795,3 \\
Всего & 1181,8 & 1749,7 \\
Естественный прирост & 832,8 & 18,5 \\
\hline
\end{tabular}

Казалось бы, надо радоваться тому, что фактическое число смертей в 1972 г. оказалось намного меньше, чем гипотетическое, соответствующее половозрастной структуре Германии. Однако надо учитывать, что число смертей зависит от числа подверженных риску смерти людей различных возрастов. При российской численности населения 1972 г., но при половозрастной структуре населения Германии, в России было бы на 11,4 млн человек в возрасте 50 лет и старше (в том числе - 6,7 млн мужчин) больше, чем на самом деле, соответственно и смертей было бы больше. Но этих людей уже не было на свете, они не дожили до 1972 г.

1972 г. не был, конечно, исключением. Огромная часть тех, кто должен был в силу возраста умирать в 1970-е - 1980-е годы, умерли раньше, в основном остались на полях войны. Если применить половозрастные пропорции населения Германии к фактическому населению России и рассчитать гипотетический естественный прирост населения России при сохранении российских повозрастных показателей рождаемости и смертности за длительный период, то можно увидеть, что естественная убыль населения появилась бы в России всего на год позже, чем в Германии, в 1973 году, а никак не в 1992 (рисунок 19). 


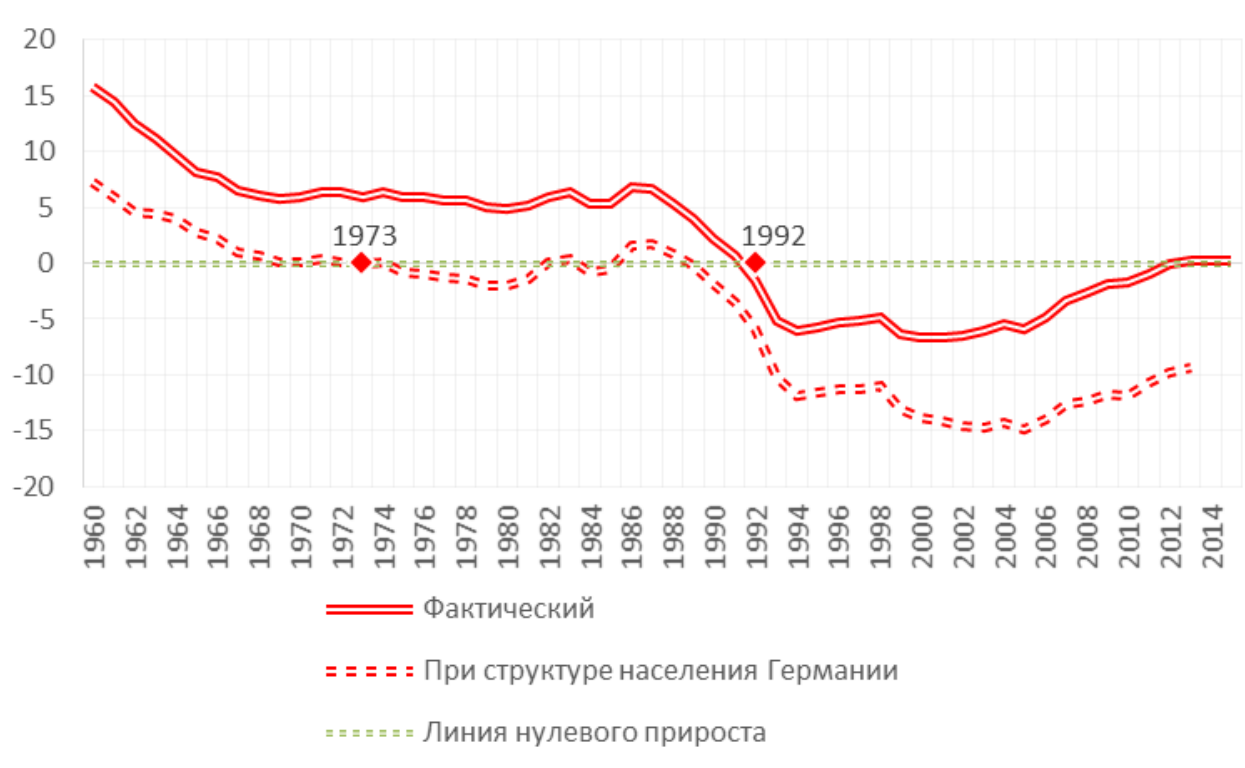

Рисунок 19. Коэффициент естественного прироста населения России фактический и гипотетический при половозрастной структуре населения Германии, \%о

\section{НАСЕЛЕНИЕ В РАБОЧЕМ ВОЗРАСТЕ И ДЕМОГРАФИЧЕСКАЯ НАГРУЗКА}

Порожденные войной циклические колебания численности поколений имеют огромное экономическое, а возможно, и политические значение, которое не всегда осознается.

В частности, они приводят к крайне неравномерной динамике численности трудовых ресурсов, формируемой поколениями, вступающими в рабочий возраст и выходящими из него. На рисунке 20 показаны ежегодные соотношения чисел молодых людей, вступающих в рабочий возраст, и пожилых людей, выходящих из него, начиная с 1959 г. (в качестве нижней и верхней границ рабочего возраста приняты 20 и 60 лет). За это время Россия пережила по меньшей мере три периода ухудшения соотношения «входвыход» для рабочих возрастов, когда малочисленные поколения работников, родившиеся в периоды низкой рождаемости (война и два ее «эха» - вокруг 1968 и 1993 г.), приходили на смену многочисленным поколениям, родившимся на 40 лет ранее. Виден и еще один период ухудшения этого соотношения, правда, не столь значительного, который совпадает не со снижением численности входящих, а с ростом численности выходящих поколений, родившихся в период кратковременного подъема рождаемости в конце 1930-х годов. 


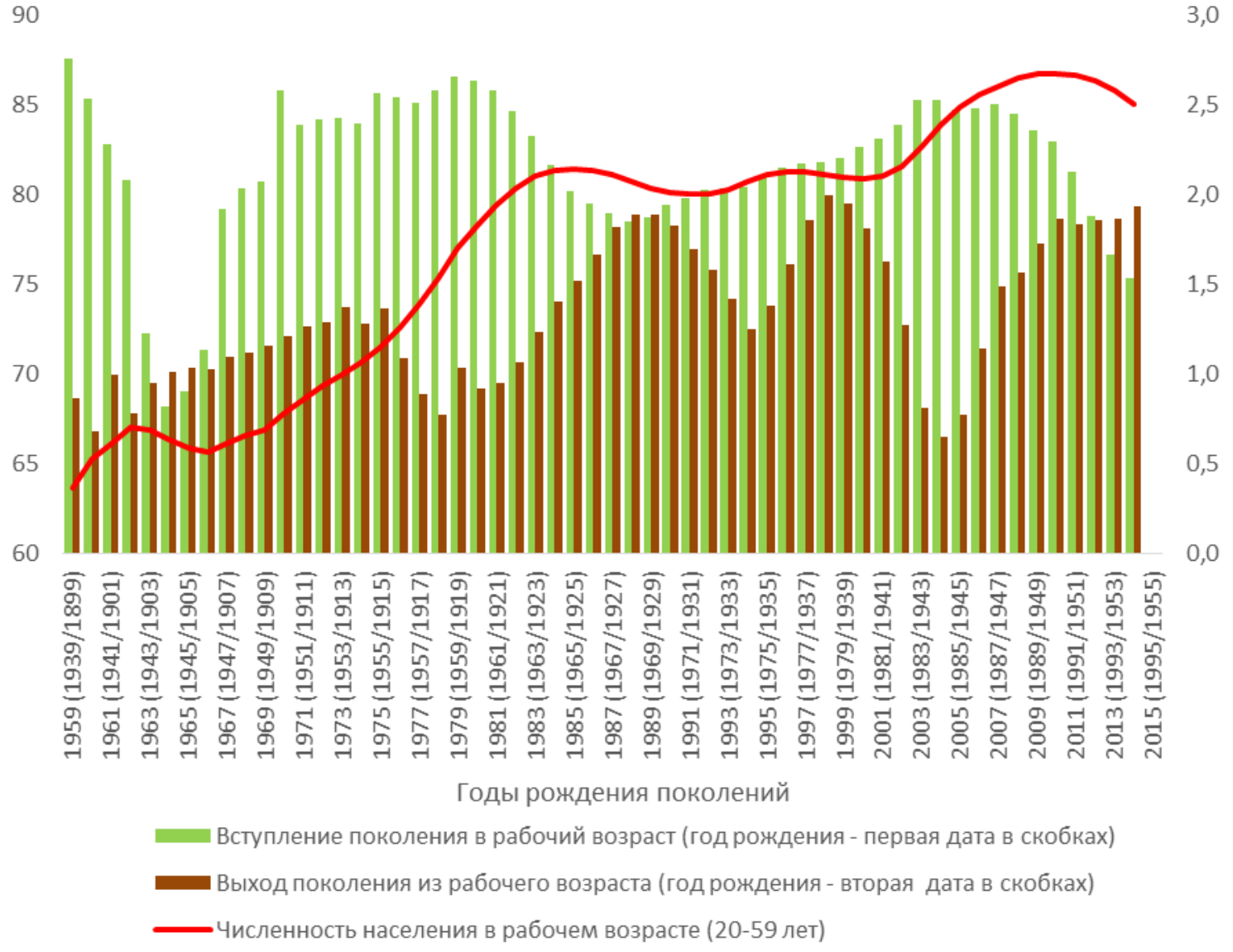

Рисунок 20. Население в рабочем возрасте в 1959-2014 гг. (левая ось), вступление в этот возраст (в 20 лет) и выход из него (в 60 лет) по поколениям (правая ось), млн человек

Источник: Демографический ежегодник России за разные годы.

Результатом циклически меняющегося соотношения входящих и выходящих поколений становится волнообразная динамика численности населения в рабочих возрастах (рисунок 21), она отнюдь не способствует устойчивому росту экономики, которой все время приходится приспосабливаться к меняющейся ситуации на рынке труда.

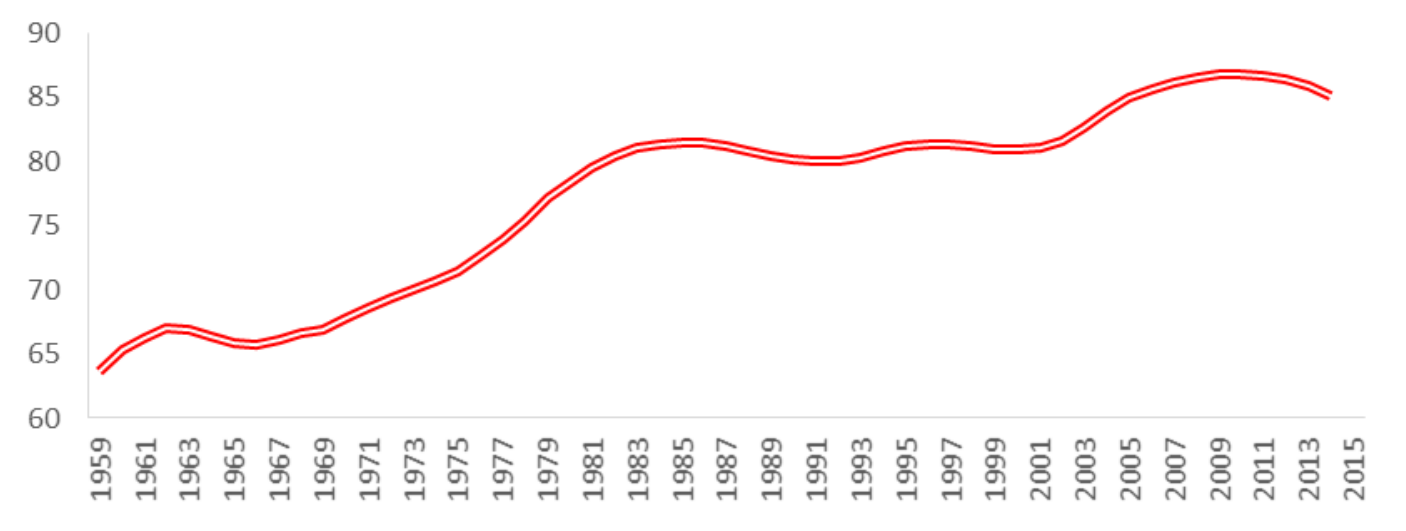

Рисунок 21. Население в рабочем возрасте (20-59 лет), млн человек

Источник: Демографический ежегодник России за разные годы. 
Но, вероятно, еще большее экономическое и социальное значение имеют перепады в величине демографической нагрузки на одного работающего, а значит, и бремени социальных расходов на здравоохранение, образование, социальное обеспечение неработающего населения, т.е. в основном населения в дорабочих и послерабочих возрастах.

Если вести отсчет от переписи населения 1959 г., то общей тенденцией изменений совокупной демографической нагрузки было ее уменьшение, обусловленное снижение нагрузки детьми, которое долгое время успешно противостояло росту нагрузки пожилыми. При этом обе части демографической нагрузки, некогда очень сильно различавшиеся, сближались. Если в 1959 г. нагрузка пожилыми (60 лет и старше) составляла 17 на 100 человек в возрасте 20-59 лет, а нагрузка детьми (до 20 лет) - 67 на 100, то к 2014 г. они почти сравнялись: соответственно 33 и 36 на 100 (рисунок 22). Но мы уже знаем, что все подобные изменения на протяжении послевоенного периода имели колебательный характер, а это приводило к существенным перепадам демографической нагрузки за относительно короткое время. Так, совокупная нагрузка детьми и пожилыми была очень высокой во второй половине 1960-х годов (94 человека в дорабочих и послерабочих возрастах на 100 человек в рабочих), а к 1982-1983 гг. сократилась более чем на 20\% - до 74 на 100. Затем менее чем за 10 лет она снова выросла на 15\% - до 84 на 100 в 1992 г. После этого нагрузка медленно сокращалась на протяжении 1990-х годов и быстро - в 2000-е, достигнув в первом десятилетии XXI века небывало низкого уровня: минимум (65 на 100 или почти на четверть меньше, чем в 1992 г. и более чем на 30\% меньше, чем в конце 1960 х) был достигнут в 2008-2011 гг., затем начался новый рост, который неизбежно будет продолжаться.

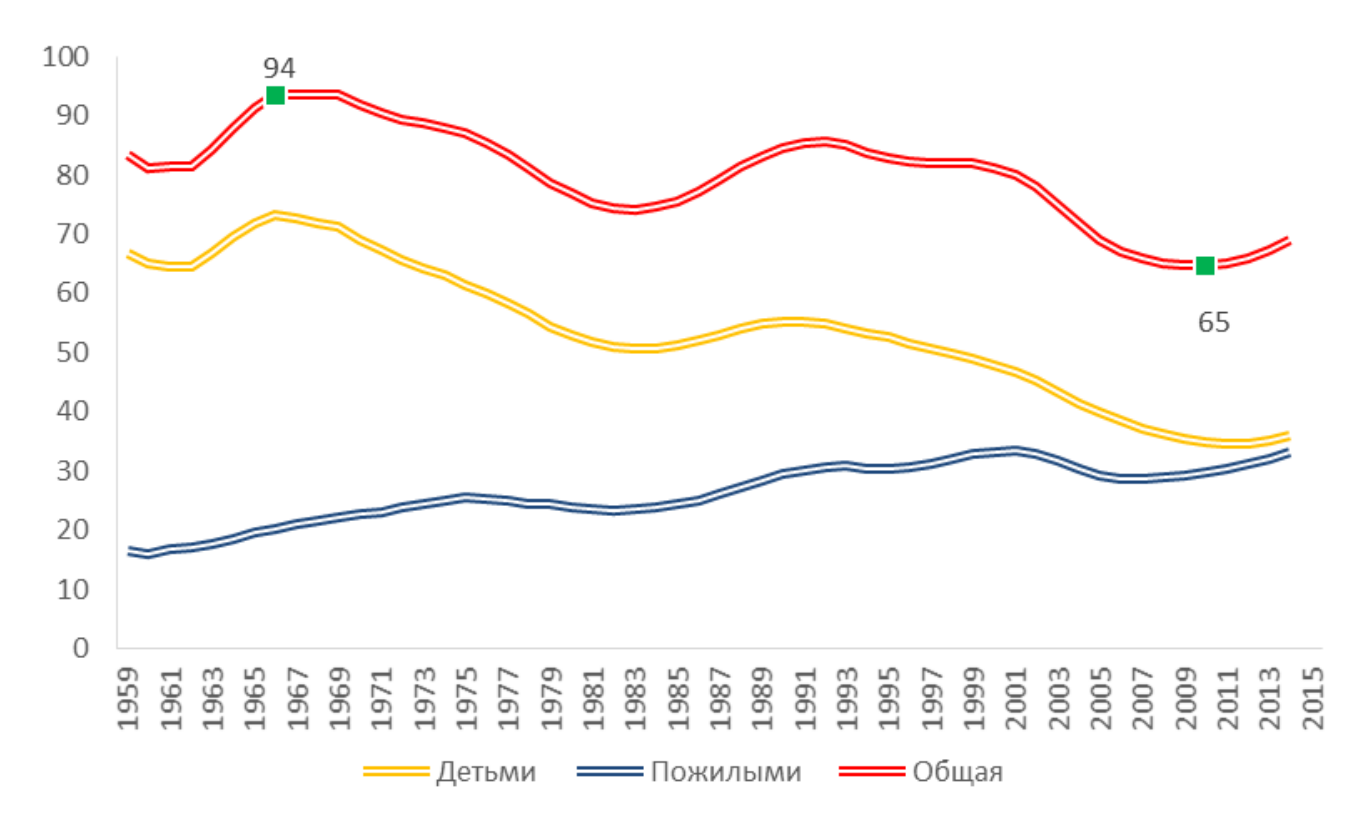

Рисунок 22. Демографическая нагрузка на 100 человек в рабочем возрасте (20-59 лет)

Источник: Демографический ежегодник России за разные годы.

Общественное мнение и даже многие эксперты, не говоря уже о политиках, обычно не придают большого значения подобным изменениям, если эти изменения не получают 
очень явного и, как правило, негативного проявления. Благоприятные (а иногда даже и неблагоприятные) демографические изменения вследствие запущенных войной колебаний численности поколений власти всегда склонны истолковывать в свою пользу, находить в них плоды проводимой ими политики, забывая о том, что и в тех, и в других случаях речь идет об отзвуках большой беды.

В 2000-е годы мало кто отдавал себе отчет как в том, что в стране сложилась исключительно благоприятная ситуация с демографической нагрузкой, так и в том, что эта ситуация была подарком из далекого и не очень радостного прошлого и не может сохраняться долго.

Демографическое старение как следствие демографического перехода идет во всех странах, в том числе и в России, но в России оно несколько раз на короткое время приостанавливалось, когда старших возрастов достигали поколения, родившиеся в годы лихолетий первой половины XX века (рисунок 23). В это время демографическая нагрузка пожилыми, а значит, и нагрузка на пенсионную систему, не росла, а сокращалась, тогда как легко предсказуемое возобновление роста нагрузки всегда казалось неожиданным.

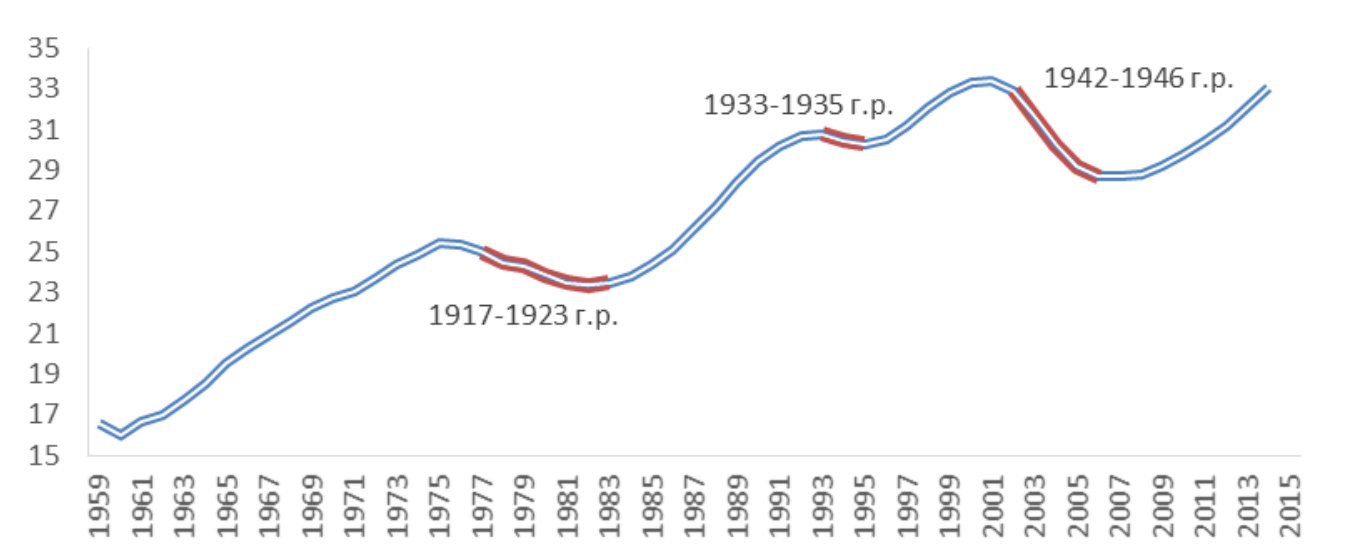

\section{Рисунок 23. Нагрузка пожилыми и годы достижения 60 лет разными поколениями, на 100 лиц в возрасте 20-59 лет}

Источник: Демографический ежегодник России за разные годы.

Самое большое сокращение произошло совсем недавно, в минувшем десятилетии, немалая часть экономического благополучия «тучных» 2000-х годов обусловлена небывало низкой демографической нагрузкой в результате приостановившегося старения населения. Приостановилось же оно потому, что в пожилые (пенсионные) возраста в это время входили малочисленные поколения, родившиеся в катастрофические военные годы. Экономика и политика извлекли из этого все возможные выгоды.

Но за малочисленными военными поколениями шли многочисленные послевоенные, и это влекло за собой новый рост демографической нагрузки в целом и нагрузки на пенсионный фонд, в частности (рисунки 24 и 25). 


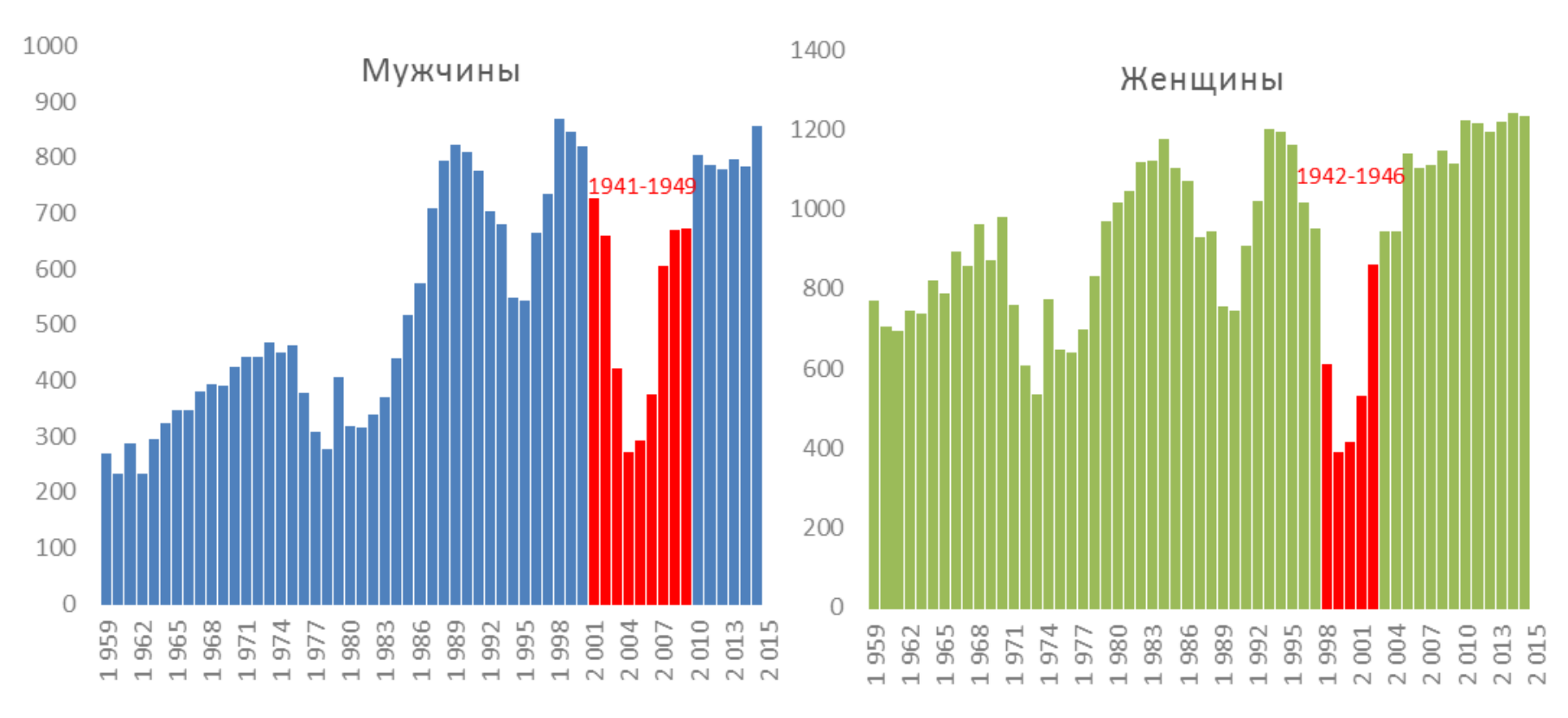

Рисунок 24. Число мужчин и женщин, достигавших пенсионного возраста (55 лет для женщин и 60 лет для мужчин) в 1959-2014 гг., тыс.

Источник: Демографический ежегодник России за разные годыл.

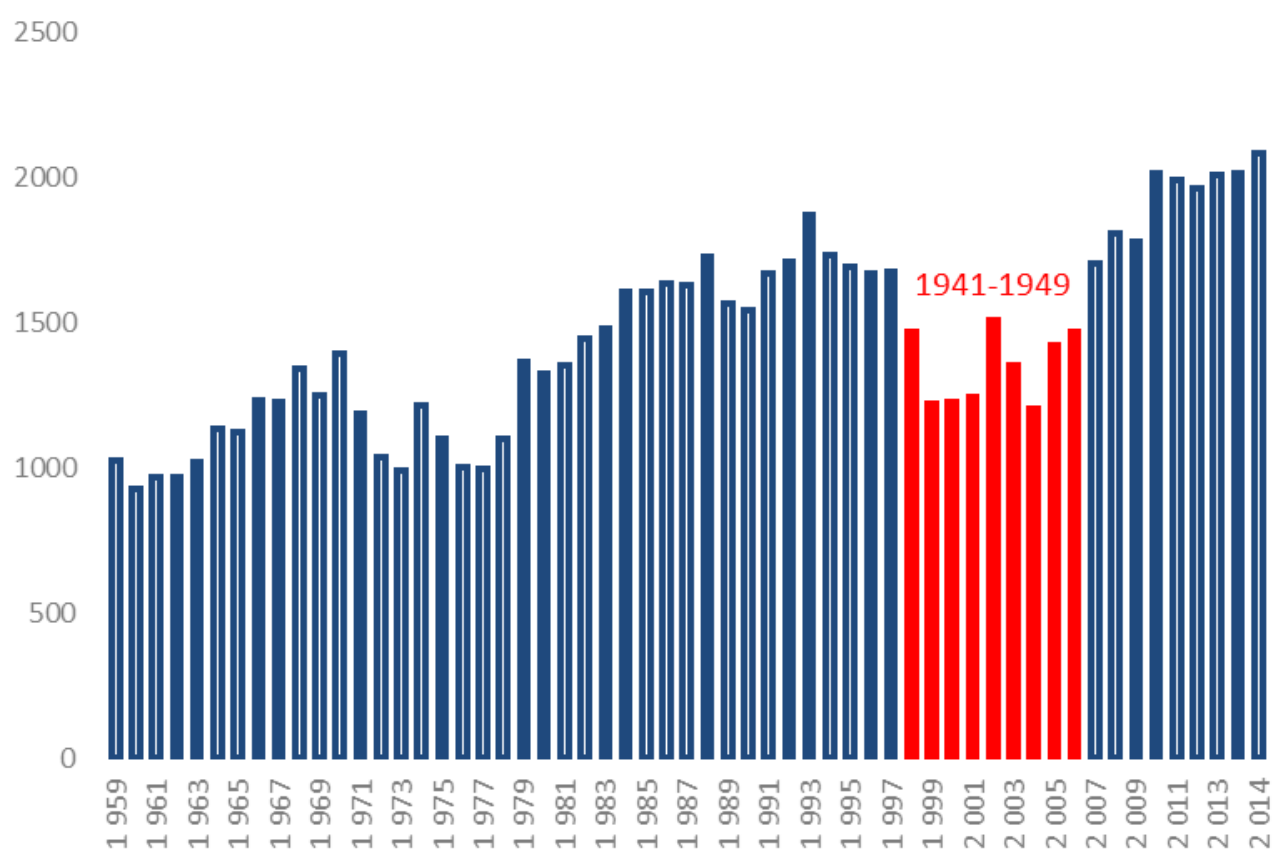

Рисунок 25. Население обоих полов, достигавшее пенсионного возраста (55 лет для женщин и 60 лет для мужчин) в 1959-2014 гг., тыс.

Источник: Демографический ежегодник России за разные годы.

Этот рост кажется особенно большим, потому что он идет после «ямы», образованной военными поколениями. Он был вполне предсказуемым, но для многих оказался неожиданным, и ему стали придумывать разные объяснения вроде того, что дается в «аналитическом докладе», подготовленном по поручению министра здравоохранения. В 
нем говорится, что доля людей старшего возраста в стране выросла с 20,5\% в 2006 г. до $23,5 \%$ и поясняется, что это произошло из-за "демографических изменений, приведших к увеличению продолжительности жизни"4.

\section{МОГЛИ ЛИ ВОЕННЫЕ ПОТЕРИ БЫТЬ МЕНЫШИМИ?}

Война есть война, воюющие стороны несут неизбежные людские потери. Но таких потерь, какие понес СССР в 1941-1945 гг., в истории еще не было. Оценки этих потерь сильно разнятся. Л. Рыбаковский приводит сводку 28 различных оценок, которые колеблются от 7 млн человек, названных Сталиным в 1946 г., до 46 млн, исчисленных одним из исследователей [Рыбаковский 2010: 26]. Но все же основная масса оценок концентрируется в интервале 26-27 млн человек, из которых примерно половина (13 млн по оценке Л. Рыбаковского [Рыбаковский 2010: 103]) приходится на Россию. Если исходить из этих цифр, то на долю СССР пришлось от трети до половины всех людских потерь стран, участвовавших во Второй мировой войне [Вишневский 1998: 387], а на долю России - от $16-17 \%$ до 25\%, и неудивительно, что демографическое эхо этих потерь Россия слышит и по сей день.

Чем объяснить такие высокие потери? Победа в войне была необходима, но разве ее нельзя было добиться не столь дорогой ценой? Были ли эти потери обусловлены невыгодным для СССР соотношением сил? Неожиданностью войны? Ошибками политического руководства страны, неправильно оценившего международную ситуацию накануне войны или не сумевшего сделать выводы из ее оценки?

Чтобы попытаться ответить на эти вопросы, нам придется вернуться в 1939 г., с которого мы начали нашу статью. Уже упоминавшийся XVIII съезд ВКП(б), главное событие тогдашней политической жизни СССР, важен для нашей темы не только потому, что Сталин назвал на нем численность населения СССР. Гораздо важнее то, что на нем была дана оценка международной ситуации, связанной с приближавшейся войной.

В частности, в докладе Сталина говорилось об уже начавшейся новой империалистической войне, характерная черта которой состояла в том, что «она не стала еще всеобщей, мировой войной. Войну ведут государства-агрессоры, всячески ущемляя интересы неагрессивных государств, прежде всего Англии, Франции, США, а последние пятятся назад и отступают, давая агрессорам уступку за уступкой» [Сталин 1997: 296]. Под государствами-агрессорами понимались Германия, Италия и Япония, и при этом подчеркивалось, что «неагрессивные, демократические государства» «располагают громадными возможностями» и «взятые вместе, бесспорно сильнее фашистских государств и в экономическом и в военном отношении» [Сталин 1997: 296-297].

Тема превосходства над фашистскими государствами получила развитие в следующем после Сталина докладе делегации ВКП(б) в Исполкоме Коминтерна (ИККИ), с

4 Дольше жить, чтобы больше работать. Минздрав и Росстат исследуют поводы для увеличения пенсионного возраста. "Коммерсантъ" №145 от 13.08.2015. 
которым выступил Д.З. Мануильский. «Для того, чтобы нанести поражение фашистским агрессорам, нужны действия, подкрепленные аргументами материальной силь, действия государств, против которых, по существу направлена фашистская агрессия (Франция, Англия, США). < ..> Для большой серьезной войны фашистская Германия не готова: у нее нет достаточно сырья, продовольствия, ее финансовое положение критическое, ее берега уязвимы для морской блокады, в ее армии недохватка командного состава, ее тыл - опасный для фашизма тыл. Преимущества материальной силы, несомненно, на стороне так называемых демократических государств. Эти государства располагают населением в $m p u$ раза больше, чем блок агрессоров, производят стали в 11/2-2 раза больше, вырабатывают в два раза больше электроэнергии, выпускают в четырнадцать раз больше автомобилей, добывают в пятьдесят пять раз больше жидкого топлива, в девять раз больше текстильного сырья, в четыре раза больше продовольствия; они могу покрыть полностью свои сырьевые потребности, в то время как блок агрессоров имеет даже в мирное время дефицит в размере 50-55\%; их наличные золотые запасы в сорок девять раз превосходят резервы фашистских государств. Их производственные возможности в самолетостроении, моторизации армии, ее военно-технической оснащенности далеко превосходят самые смелые расчеты фашистского блока; морской флот Франции, Англии и США в два раза сильнее, чем флот Германии, Италии и Японии» [Съезд ВКП(б) 1939: 57].

Делегаты съезда были настроены очень бодро. Сталин иронизировал по поводу «фашистских заправил» и зал чутко откликался на его юмор, об этом свидетельствуют ремарки в стенограмме съезда, опущенные, правда, при публикации доклада в собрании сочинений Сталина. «Фашистские заправилы раньше, чем ринуться в войну, решили известным образом обработать общественное мнение, то есть ввести его в заблуждение, обмануть его. Военный блок Германии и Италии против интересов Англии и Франции в Европе? Помилуйте, какой же это блок! "У нас" нет никакого военного блока. "У нас" всего-навсего безобидная “ось Берлин - Рим”, то есть некоторая геометрическая формула насчет оси. (Смех). Военный блок Германии, Италии и Японии против интересов США, Англии и Франции на Дальнем Востоке? Ничего подобного! "У нас" всего-навсего безобидный “треугольник Берлин - Рим - Токио”, то есть маленькое увлечение геометрией. (Общий смех)» [Съезд ВКП(б) 1939: 12]. «Вполне возможно, что в Германии имеются сумасшедшие, мечтающие присоединить слона, то есть Советскую Украину, к козявке, то есть к так называемой Карпатской Украине. И если действительно имеются там такие сумасброды, можно не сомневаться, что в нашей стране найдется необходимое количество смирительных рубах для таких сумасшедших (Взрыв аплодисментов)» [Съезд ВКП(б) 1939: $13-14]$.

Следует признать, что если отбросить пропагандистскую риторику, то представленный на Съезде анализ соотношения сил на мировой арене был верным. В общем, это подтвердил и ход войны, правда, с немалыми оговорками.

Когда война закончилась, снова прозвучала мысль об изначальном превосходстве победителей, о «величайших преимуществах коалиции демократических государств, которые обладали значительно превосходящими возможностями и резервами в экономике и технике для победы в мировой войне. Эти преимущества видны также из сравнения численности населения: демократические государства - СССР, США и Англия - имели 
численность населения в 372 млн человек, в то время как фашистские государства Германия, Япония и Италия - имели 186 млн человек» [Вознесенский 1948]. И снова это не просто личная точка зрения пусть и весьма высокопоставленного тогда автора. После выхода его книги она была удостоена Сталинской премии первой степени, и имеются свидетельства, что ее «ещё в рукописи прочитал с карандашом в руках Сталин и сделал свои пометки и даже некоторые вставки» [Съезд КПСС 1962: 184].

Но как совместить такое превосходство с такими потерями?

Всякое сравнение хромает, но все же некоторые параллели напрашиваются. 7 декабря 1941 г. несколько сот японских самолетов («без объявления войны») атаковали американскую военную базу Пёрл-Харбор, после чего США, Великобритания и ряд их союзников объявили войну Японии.

Япония была совсем не простым противником. Ее население в 1941 г. (73 млн человек) было примерно таким же, как население Германии (72 млн), тогда как население США в это время (132 млн человек по переписи 1940 г.) составляло примерно две трети населения СССР (197 млн в июне 1941 г.). Кроме того, Япония владела колониями (включая Корею) с населением свыше 30 млн человек, контролировала значительные территории Китая, в том числе марионеточное государство Манчжоу-го с населением свыше 40 млн человек. Япония давно готовилась к войне и вела войну, она оккупировала значительные территории в Азии и Океании, развитие ее промышленности было подчинено военным задачам, политика страны находилась под контролем военных, большинство населения фанатично поддерживало агрессивные имперские цели руководства страны.

Начавшаяся после Пёрл-Харбора война шла на огромном Тихоокеанском театре, первый ее этап складывался неудачно для США и их союзников, но затем наступил перелом. Поворотной точкой считается морское сражение у атолла Мидуэй в июне 1942 г. Война продолжалась еще более трех лет, но уже при явном превосходстве США. Разница военно-экономических потенциалов Японии и США была огромной, и это предрешило исход войны: японцы были изгнаны со всех захваченных ими территорий, военные действия были перенесены на территорию Японии. Война США против Японии нейтрализовала, а затем и ликвидировала чрезвычайно опасную для СССР угрозу, исходившую от одной из вершин «треугольника», ироническое упоминание о котором в докладе Сталина было встречено «общим смехом» делегатов XVIII Съезда ВКП(б).

В ходе этой совсем не простой войны с Японией, длившейся, как и Великая отечественная, с 1941 по 1945 г., американские вооруженные силы потеряли убитыми, умершими в плену и пропавшими без вести около 120 тыс. военнослужащих [Army 1946 : 8; CRS (2001): 3]. Это меньше, чем безвозвратные потери советских войск в советскофинляндской войне 1939-1940 гг. (127 тыс. погибших), и всего в 10 раз больше, чем было потеряно примерно за 25 дней военных действий против Квантунской армии в Маньчжурии после вступления СССР в войну против Японии 9 августа 1945 г. (свыше 12 тыс. человек) [Гриф секретности 1993: 121, 223]. К этому времени военная мощь Японии была уже ослаблена, Япония дважды подверглась атомной бомбардировке. 15 августа император Хирохито, выступая по радио с обращением к нации, объявил о капитуляции Японии, но 
Квантунская армия продолжала сопротивляться до 2 сентября, не имея, конечно, никаких перспектив.

А как сработал зафиксированный на XVIII Съезде ВКП(б) расклад мировых сил в случае СССР?

На протяжении нескольких месяцев после съезда Советский Союз вел переговоры с Англией и Францией и одновременно с Германией. Имеется огромная литература, в которой подробно обсуждаются все вопросы европейской дипломатической игры лета 1939 г., осуждаются или оправдываются тогдашние шаги советского руководства. Но для нас сейчас важен результат: советская дипломатия не достигла взаимопонимания с «неагрессивными демократическими государствами», зато довольно быстро нашла общий язык с авантюристическими «фашистскими заправилами», что привело к подписанию 23 августа советско-германского Пакта о ненападении («Пакт Молотова-Риббентропа»), а затем (28 сентября) и Договора о дружбе и границе.

Как утверждал в своих воспоминаниях генерал Судоплатов, один из руководителей советской разведки, курировавший перед войной как раз ее немецкое направление, «политика Сталина по отношению к Гитлеру основывалась на правильном соображении, что враждебность западного мира и Японии к советскому строю сделает изоляцию СССР от международного сообщества постоянным фактором» [Судоплатов 1997: 146-147]. Смысл этой фразы понять трудно, особенно на фоне того, что говорил на Съезде за несколько месяцев до того о «политике по отношению к Гитлеру» сам Сталин. Гораздо понятнее размышления разведчика о том, что «тайные консультации Гитлера, Риббентропа и Молотова о возможном соглашении стратегического характера между Германией, Японией и Советским Союзом создали у Сталина и Молотова иллюзорное представление, будто с Гитлером можно договориться», и его недоумение по поводу того, что «военное руководство и окружение Сталина питали иллюзию, будто мощь Красной Армии равна мощи сил вермахта, сосредоточенных у наших западных границ. Откуда такой просчет?» «Никто в службе госбезопасности серьезно не изучал реальное соотношение сил на советско-германской границе» [Судоплатов 1997: 175, 180-181].

Но, кажется, и сам Судоплатов не считал, что при той степени доверия, какая установилась между руководством двух стран, подобное изучение было необходимым. Объясняя, почему разведка отказалась от использования ценного агента, имевшего доступ к высшим должностным лицам Рейха, он пишет: «Перед тем как Германия развязала против нас войну, фактически не было таких проблем, где бы можно было его использовать для прощупывания позиции немцев по тому или иному деликатному вопросу: ведь все это время Молотов и наш посол Деканозов поддерживали конфиденциальные отношения с Риббентропом и послом Германии Шулленбургом» [Судоплатов 1997: 172]. А чем же тогда занималась разведка «на немецком направлении»? «Как только Сталин узнал о том, что немецким генштабом проводятся учения по оперативно-стратегическому и материальнотехническому снабжению на случай затяжной войны, он немедленно отдал приказ ознакомить немецкого военного атташе в Москве с индустриально-военной мощью Сибири. В апреле 1941 года (!) ему разрешили поездку по новым военным заводам, выпускавшим танки новейших конструкций и самолеты. Через свою резидентуру в Берлине 
мы распространяли слухи в министерствах авиации и экономики, что война с Советским Союзом обернется трагедией для гитлеровского руководства» [Судоплатов 1997: 176]. Так мы готовились к войне.

Л. Рыбаковский, едва ли не больше других занимавшийся изучением военных потерь СССР и России, ввел в оборот странную формулу: «Сталин, идя на заключение с фашистской Германией пакта о ненападении, не совершил ошибки, но допустил огромный стратегический просчет» [Рыбаковский 2000: 94; 2010: 19]. Но его общий вывод все же гласит, что «огромные размеры людских потерь во многом обусловлены преступной деятельностью Сталина и его окружения [в книжном варианте - «клики»]; стратегическими просчетами, допущенными накануне войны; упорным нежеланием считаться с реалиями войны, особенно на ее первой стадии» [Рыбаковский 2000: 94; 2010: 18].

Видимо, Сталин и его окружение достаточно ясно осознавали, что такие потери не были оправданы, и сделал все, чтобы скрыть их подлинные масштабы. Это проявилось не только в том, что Сталин сообщил всему миру совершенно нереальную величину потерь 7 млн человек (заведомо зная, что она больше), но и в том, что он запретил любые попытки учета послевоенного населения СССР. Хорошо понимая нежелание Сталина называть истинную величину потерь, тогдашний начальник ЦСУ СССР В. Старовский все же, полагая, что «для практических нужд необходимо иметь данные о современной численности... и... составе населения», предложил провести единовременный учет населения, специально оговорив, что речь идет не о переписи населения и что «в отличие от итогов переписи населения итоги учета не будут подлежать публикации, как это принято в международной практике», но получил указание Сталина «отложить до конца пятилетки» [Демографическая модернизация России 2006: 459]. После этого указания, полученного 29 августа 1947 г., Сталин прожил более 5 лет, но вопрос об учете, а тем более о переписи населения больше не возникал. И даже после смерти Сталина величина военных потерь населения СССР долгое время была окружена завесой секретности, и тот же В. Старовский, как мог, противился ее рассекречиванию. Сохранилась секретная записка «особой важности» в ЦК КПСС от 14 ноября 1956 г. Вот ее полный текст ${ }^{5}$.

«Особой важности.

Тов. Шепилов просит телеграфировать подлежащие публикации иүифры о людских потерях советской армии и советского народа за годы второй мировой войньл.

В связи с этим докладываю:

а) в интервью И.В. Сталина, опубликованном в печати 14 марта 1946 года, было сказано: «... В результате немеикого вторжения Советский Союз безвозвратно потерял в боях с немцами, а также благодаря немецкой оккупации и угону советских людей на немецкую каторгу - около семи миллионов человек. Иначе говоря, Советский Союз потерял

${ }^{5}$ РГАЭ. Ф. 1562. Оп.33 Д.2990. Л.75. 
людьми в несколько раз больще, чем Англия и Соединенные Штаты Америки, вместе взятые».

б) по расчетам ЦСУ убыль населения СССР за годы войны в результате потерь советской армии истребления советских людей оккупантами и превышения смертности над рождаемостью составила более 20 миллионов человек;

в) из опубликованных в сборнике ЦСУ иифр о населении СССР за 1940 год (191,7 млн.) и на апрель 1956 года (200,2 млн.), а также из данных о приросте населения, опубликованных за последние годы, можно сделать вывод, что потери в СССР в войну составили не 7 млн., а значительно больше.

В связи с этим считал бы необходимым дать тов. Шепилову указание или не называть вовсе ицируу потерь, ограничившись формулировкой «многие миллионы», или же назвать цүифру - свыше 20 млн. человек дав ее, примерно, в следующей редакции:

«Советский Союз за период Великой Отечественной войны потерял в боях с захватчиками, в результате истребления населения оккупантами, а также от снижения рождаемости и увеличения смертности, особенно в оккупированных районах, свыме 20 миллионов человек».

\section{Прошу указаний».}

Шепилов в то время по своему статусу был значительно выше Старовского, тем не менее он, по-видимому, получил соответствующее «указание», потому что новая цифра потерь («более двух десятков миллионов жизней советских граждан») была названа Хрущевым лишь спустя 5 лет [Хрущев 1961: 8], а затем подверглась корректировке уже в точном соответствии с рекомендацией Старовского («свыше 20 миллионов человек») [Брежнев 1965: 15]. Как справедливо отмечает Д. Богоявленский, «можно считать, что основа цифр и Хрущева, и Брежнева впервые указана Старовским в этой записке. Кстати, и «горбачевские» «почти 27 млн» формально вполне попадают в определение «свыше 20 миллионов человек» из письма начальника ЦСУ СССР. Видимо, ЦСУ все же вело свой собственный счет потерь, и в этом - немалая заслуга Старовского. Но верно и то, что он считал совершенно нормальными сокрытие от народа и от всего мира истинных масштабов потерь и искал способов продолжать утаивать имевшиеся в его распоряжении цифры в изменившейся политической ситуации. Даже в своем сверхсекретном письме Старовский не называет конкретных цифр, а приводит уклончивые и «округленные» оценки. Кроме того, он ошибался, а может быть и лукавил, включая в предлагаемую им формулировку потери от снижения рождаемости. Такие потери, пусть и гипотетические, конечно, были, но с ними «цена Победы» оказалась бы еще большей» [Богоявленский 2012].

Она и оказалась большей, все послевоенные переписи населения свидетельствуют об этом, как и о том, с каким трудом и как долго залечивались (и все еще продолжают залечиваться) нанесенные войной демографические раны. И остается вопрос: почему они оказались так глубоки? Знаменитые слова из песни Окуджавы: «Нам нужна одна победа, одна на всех - мы за ценой не постоим» - не дают всех ответов на этот вопрос. Советский Союз сражался с сильным, но не с более сильным противником, он воевал на стороне, 
намного более мощной в экономическом и военном отношении, что, как мы видели, было ясно тогдашнему политическому руководству и до, и после войны.

Сам факт, что вместо того, чтобы искать ответ на вопрос о причинах небывалых потерь, оно сделало все, чтобы избежать самого вопроса, говорит о многом. Оно встало на путь преуменьшения потерь и их засекречивания в надежде на то, что все забудется и время смоет все следы, в памяти же останется одна победа.

Но нет ничего тайного, что не сделалось бы явным, ни сокровенного, что не сделалось бы известным и не обнаружилось бы (Лука, 8,17$)$.

\section{ЛИТЕРАТУРА}

Андреев Е.М., Л.Е. Дарский, Т.Л. Харькова (1993). Население Советского Союза: 1922 1991. М.: Наука.

Андреев Е.М., Л.Е. Дарский, Т.Л. Харькова (1998). Демографическая история России: 1927-1959. М.: Информатика.

База данных Демоскопа Weekly. URL: http://demoscope.ru/weekly/app/app40nrr.php (дата обращения: 22.06.2016).

Башкин А., Е. Назаров (2014). Была ли перепись 1939 г. сфальсифицирована? URL: http://statehistory.ru/4567/Byla-li-perepis-1939-g--sfalsifitsirovana-/ (дата обращения: 22.06.2016).

Богоявленский Д. (2012). Как утаивали величину военных потерь // Демоскоп Weekly. №513-514. URL: http://demoscope.ru/weekly/2012/0513/arxiv01.php (дата обращения: 22.06.2016).

Брежнев Л.И. (1965). Великая победа советского народа. М.: Политиздат.

Вишневский А. (1998). Серп и рубль. Консервативная модернизация в СССР. М.: ОГИ.

Вишневский А.Г., Захаров С.В. (2010). Что знает и чего не знает российская демографическая статистика // Вопросы статистики. №2: 7-17.

Вознесенский Н. (1948). Военная экономика СССР в период Отечественной войны. М.: Госполитиздат.

Волков А.Г. (2014). Избранные демографические труды. М.: Изд. дом Высшей школы экономики.

Гриф секретности снят. Потери вооруженных сил СССР в войнах, боевых действиях и военных конфликтах (1993) // Под. ред. Г.Ф. Кривошеева. М: Воениздат.

Демографическая модернизация России, 1900-2000 (2006) / Под ред. А.Г. Вишневского. М.: Новое издательство.

Демографический ежегодник России 2015 (2015): Статистический сборник. М.: Росстат.

Иванова Е., А. Михеева (1998). Внебрачное материнство в России // Население и общество №28.

Ильина И.П. (1977). Влияние войн на брачность советских женщин // Брачность, рождаемость, смертность в России и в СССР / Под ред. А. Вишневского. М.: Статистика. 
Поляков Ю., В. Жиромская, Н. Араловец (2004). «Демографическое эхо» войны // Война и общество, 1941-1945. Кн. 2. М.: Наука.

Рыбаковский Л.Л. (2000). Людские потери СССР и России в Великой отечественной войне // Социологические исследования. №8.

Рыбаковский Л.Л. (2010). Людские потери СССР и России в Великой отечественной войне. М.: Экон-Информ.

Сталин И.В. (1997). Отчетный доклад на XVIII съезде партии о работе ЦК ВКП(б) 10 марта 1939 года // Сталин И.В. Сочинения. Т.14. М.: «Писатель».

Судоплатов П.А. (1997). Спецоперации. Лубянка и Кремль 1930-1950 годы. М.: ОЛМАПРЕСС.

Съезд ВКП(б) (1939). XVIII Съезд Всесоюзной Коммунистической партии (б) 10-21 марта 1939 г. Стенографический отчет. ОГИЗ.

Съезд КПСС (1962). XXII съезд КПСС. 17-31 октября 1961 года. Т. 2. М.: Политиздат.

Тольц М.С. (2004). Тайны советской демографии // Демоскоп Weekly. №171-172. URL: http://www.demoscope.ru/weekly/2004/0171/analit06.php\#00 (дата обращения: 22.06.2016).

Тольц М.С. (2014). От абортного термидора к законодательному либерализму. Политика в области брачно-семейных отношений как зеркало истории СССР // Развитие населения и демографическая политика. Демографические исследования, вып. 23-й. Памяти А.Я. Кваши / Под ред. М.Б. Денисенко и В.В. Елизарова. М.: МГУ.

Указ (1944). Указ Президиума Верховного совета СССР (1944). «Об увеличении государственной помощи беременным женщинам, многодетным и одиноким матерям, усилении охраны материнства и детства, об установлении почетного звания Матьгероиня и учреждении ордена Материнская слава и медали Медаль материнства». URL: https://www.lawmix.ru/docs_cccp/3096

Харчев А.Г. (1979). Брак и семья в СССР. М.: Мысль.

Хрущев Н.С. (1961). Письмо премьер-министру Швеции Т. Эрландеру // Международная жизнь. № 12.

Цаплин В.В. (1989). Статистика жертв сталинизма в 30-е годы // Вопросы истории, №4.

ЦСУ СССР (1975). Население СССР 1973. Статистический сборник. М.: Статистика: 150.

Army (1946). Army battle casualties and nonbattle deaths in World War II. Final Report. 7 December 1941 - 31 December 1946. Statistic and Accounting Branch of Adjutant General.

CRS (2001). CRS Report for Congress. U.S. Prisoners of War and Civilian American Citizens Captured and Interned by Japan in World War II: The Issue of Compensation by Japan. Updated July 27, 2001.

Statistisches Bundesamt (2016). Wiesbaden. Animierte Bevölkerungspyramide. URL: https://www.destatis.de/bevoelkerungspyramide/\#!y=1967\&v=2 (дата обращения: 22.06.2016). 


\title{
DEMOGRAPHIC CONSEQUENCES OF THE GREAT PATRIOTIC WAR *
}

\author{
$\underline{\underline{\text { ANATOLY VISHNEVSKY }}}{ }^{, * *}$
}

\begin{abstract}
75 years have passed since the beginning of the Great Patriotic War, yet its demographic consequences, felt by Russia throughout all of this time, even now have not been completely overcome. The article traces the fate of the generations who fought (those born between 1890-1926), using general census data starting with the 1939 census. It is shown that $82 \%$ of women and only 53\% of men registered in the 1939 census survived until 1959. The resulting gender imbalance caused a sharp increase in the proportion of single women as a result of widowhood, and due to a shortage of suitors in the marriage market the share of non-marital births increased significantly. The war set in motion an oscillating cycle of the annual number of births which continues to this day. A relatively small number of deaths in the postwar decades, due to the fact that a huge number of people killed during the war did not live to a normal age of death, created the illusion of a safe balance of births and deaths in the 1970's-1980's. Cyclical fluctuations in the size of generations induced by the war resulted in a wave-like dynamics of the working population and demographic burden, complicating the functioning of the labor market and the implementation of economic and social programs, effects which are felt even in our day, for example, in the dynamics of pension contingents.
\end{abstract}

The author discusses the reasons for the huge military losses and suggests that if the war had not been preceded by erroneous decisions of the country's political leaders, these losses could have been much smaller.

Keywords: generations involved in the war, military losses, consequences of the war, cost of the victory, gender imbalance.

\footnotetext{
${ }^{1}$ National RESEARCh University Higher School of Economics (RUSSiA).

* THE RESUltS OF THE PROJECTS "DEMOGRAPHIC, CARRIED OUT WITHIN THE FRAMEWORK OF THE BASIC RESEARCH Program at the National ReSEARCh University Higher School of ECONOMics (HSE) IN 2016-2016, ARE PRESENTED IN THIS WORK.

** CORRESPONDENCE: avishnevsky@hse.ru

DATE RECEIVED: JANUARY 2016.
}

\section{REFERENCES}

Andreyev Ye.M., L.Ye.Darskiy, T.L. Khar'kova (1993). Naseleniye Sovetskogo Soyuza: 19221991 [The population of the Soviet Union: 1922-1991]. Moscow: Nauka.

Andreyev Ye.M., L.Ye.Darskiy, T.L. Khar'kova (1998). Demograficheskaya istoriya Rossii: 1927-1959. [Demographic history of Russia: 1927-1959]. Moscow: Informatika.

Army (1946). Army battle casualties and nonbattle deaths in World War II. Final Report. 7 December 1941 - 31 December 1946. Statistic and Accounting Branch of Adjutant General.

Bashkin A., Ye. Nazarov (2014). Byla li perepis' 1939 goda sfal'sifitsirovana? [Was the census of 1939 falsified?]. URL: http://statehistory.ru/4567/Byla-li-perepis-1939-g-sfalsifitsirovana-/ (accessed: 22.06.2016).

Baza dannykh Demoskopa Weekly [Database of Demoscope Weekly]. URL: http://demoscope.ru/weekly/app/app40nrr.php (accessed: 22.06.2016). 
Bogoyavlenskiy D. (2012). Kak utaivali velichinu voyennykh poter' [How the military losses were concealed]. Demoscope Weekly. №513-514. URL:

http://demoscope.ru/weekly/2012/0513/arxiv01.php (accessed: 22.06.2016).

Brezhnev L.I. (1965). Velikaya pobeda sovetskogo naroda [The great victory of the Soviet people]. Moscow: Politizdat.

CRS (2001). CRS Report for Congress. U.S. Prisoners of War and Civilian American Citizens Captured and Interned by Japan in World War II: The Issue of Compensation by Japan. Updated July 27, 2001.

Demograficheskaya modernizatsiya Rossii, 1900-2000 [Demographic modernization of Russia, 1900-2000] (2006). Pod red. A.G. Vishnevskogo [Ed. by A.G. Vishnevsky]. Moscow: Novoye izdatel'stvo.

Grif sekretnosti snyat. Poteri vooruzhennykh sil SSSR v voynakh, boyevykh deystviyakh i voyennykh konfliktakh [Secrecy label removed. Casualties of the armed forces of the USSR in wars, hostilities and military conflicts] (1993). G.F.Krivosheev, ed. Moscow: Voenizdat.

Il'ina I.P. (1977). Vliyaniye voyn na brachnost' sovetskikh zhenshchin [The impact of war on the Soviet women's marriages] // Brachnost', rozhdayemost', smertnost' v Rossii i v SSSR. [Nuptiality, fertility, mortality in Russia and in the USSR]. Pod red. A.G.Vishnevskogo. [Ed. by A.G. Vishnevsky]. Moscow: Statistika.

Ivanova Ye., Mikheyeva A. (1998). Vnebrachnoye materinstvo v Rossii [Extramarital motherhood in Russia] // Naseleniye i obshchestvo [Population and Society]. №28.

Kharchev A.G. (1979). Brak i sem'ya v SSSR [Marriage and family in the Soviet Union]. Moscow: Mysl'.

Khrushchev N.S. (1961). Pis'mo prem'yer-ministru Shvetsii T. Erlanderu [Letter to the Prime Minister of Sweden T. Erlander] // Mezhdunarodnaya zhizn'. №12.

Polyakov Yu., Zhiromskaya V., Aralovets N. (2004). “Demograficheskoye ekho” voyny ["Demographic echo" of the war] // Voyna i obshchestvo, 1941-1945. Kniga 2 [War and Society, 1941-1945. Vol. 2]. Moscow: Nauka.

Rybakovskiy L.L. (2000). Lyudskiye poteri SSSR i Rossii v Velikoy otechestvennoy voyne [Casualties of the USSR and Russia in the Great Patriotic War] // Sotsiologicheskiye issledovaniya [Sociological studies]. №8.

Rybakovskiy L.L. (2010). Lyudskiye poteri SSSR i Rossii v Velikoy otechestvennoy voyne [Casualties of the USSR and Russia in the Great Patriotic War]. Moscow: Econ-Inform.

S"yezd KPSS (1962). XXII s"yezd KPSS. 17-31 oktyabrya 1961 goda [XXII Congress of the CPSU. 17-31 October 1961]. T. 2. Moscow: Politizdat.

S"yezd VKP(b) (1939). XVIII S"yezd Vsesoyuznoy Kommunisticheskoy partii (bol'shevokov) 10-21 marta 1939 goda. Stenograficheskiy otchet [XVIII Congress of the All-Union Communist Party (of Bolshevics) 10-21 March 1939. Verbatim record]. Moscow: OGIZ.

Stalin I.V. (1997). Otchetnyy doklad na XVIII s"yezde partii o rabote TsK VKP(b) 10 marta 1939 goda [Progress report of the Central Committee of the CPSU (b) at the XVIII Congress of the Party. March 10, 1939] // Stalin I.V. Sochineniya [Works]. T.14. Moscow: «Pisatel'».

Statistisches Bundesamt (2016), Wiesbaden. Animierte Bevölkerungspyramide. URL: https://www.destatis.de/bevoelkerungspyramide/\#!y=1967\&v=2 (accessed: 22.06.2016).

Sudoplatov P.A. (1997). Spetsoperatsii. Lubyanka i Kreml': 1930-je -1950-je [Special operations. Lubyanka and the Kremlin: the1930s - the 1950s]. Moscow: OLMA-PRESS. 
Tol'ts M.S. (2004). Tayny sovetskoy demografii [Secrets of Soviet demographics] // Demoskop Weekly № 171-172 URL: http://www.demoscope.ru/weekly/2004/0171/analit06.php\#00 (accessed: 22.06.2016).

Tol'ts M.S. (2014). Ot abortnogo termidora k zakonodatel'nomu liberalizmu. Politika v oblasti brachno-semeynykh otnosheniy kak zerkalo istorii SSSR [From abortion Thermidor to the legislative liberalism. The marriage and family relations policy as a mirror of history of the USSR] // Razvitiye naseleniya i demograficheskaya politika [Population development and population policy]. Demograficheskiye issledovaniya. Vyp.23-y. Pamyati A.Ya. Kvashi [Population Studies. Vol.23. In memory of A.Ya. Kvasha]. Pod red. M.B. Denisenko i V.V. Yelizarova [Ed. by M.B. Denisenko and V.V. Elizarov]. Moscow: MGU.

Tsaplin V.V. (1989). Statistika zhertv stalinizma v 30-ye gody [Statistics of victims of Stalinism in the 30s] // Voprosy istorii, №4.

TSSU SSSR (1975). [Central Statistical Office of the USSR]. Naseleniye SSSR 1973 [The population of the USSR 1973]. Statisticheskiy sbornik [Statistical Yearbook]. Moscow: Statistika.

Ukaz (1944). Ukaz Prezidiuma Verkhovnogo soveta SSSR (1944). «Ob uvelichenii gosudarstvennoy pomoshchi beremennym zhenshchinam, mnogodetnym i odinokim materyam, usilenii okhrany materinstva i detstva, ob ustanovlenii pochetnogo zvaniya Mat'geroinya i uchrezhdenii ordena Materinskaya slava i medali Medal' materinstva» [Decree of the Presidium of the Supreme Soviet of the USSR (1944). "On increase of state aid to pregnant women, large families and single mothers, strengthening maternal and child health, the establishment of the honorary title of Mother-Heroine, the Order of Maternal Glory and Medal of motherhood"]. URL: https://www.lawmix.ru/docs_cccp/3096

Vishnevskiy A. (1898). Serp i rubl'. Konservativnaya modernizatsiya v SSSR [The sickle and the ruble. Conservative modernization in the USSR]. Moscow: OGI.

Volkov A.G. (2014). Izbrannyye demograficheskiye Trudy [Selected demographic works]. Moscow: Izd. dom Vysshey shkoly ekonomiki [HSE Publishing House]

Voznesenskiy N. (1948). Voyennaya ekonomika SSSR v period Otechestvennoy voyny [The war economy of the USSR during the Patriotic War]. Moscow: Gospolitizdat. 